\title{
Diagnostic indicators of non-cardiovascular chest pain: a systematic review and meta-analysis
}

\author{
Maria M Wertli", Katrin B Ruchti, Johann Steurer and Ulrike Held
}

\begin{abstract}
Background: Non-cardiovascular chest pain (NCCP) has a high healthcare cost, but insufficient guidelines exist for its diagnostic investigation. The objective of the present work was to identify important diagnostic indicators and their accuracy for specific and non-specific conditions underlying NCCP.

Methods: A systematic review and meta-analysis were performed. In May 2012, six databases were searched. Hand and bibliography searches were also conducted. Studies evaluating a diagnostic test against a reference test in patients with NCCP were included. Exclusion criteria were having $<30$ patients per group, and evaluating diagnostic tests for acute cardiovascular disease. Diagnostic accuracy is given in likelihood ratios ( $L R)$ : very good $(L R+>10, L R-<0.1)$; good ( $L R+5$ to 10, LR- 0.1 to 0.2); fair ( $L R+2$ to 5, LR- 0.2 to 0.5); or poor ( $L R+1$ to 2, LR- 0.5 to 1). Joined meta-analysis of the diagnostic test sensitivity and specificity was performed by applying a hierarchical Bayesian model.

Results: Out of 6,316 records, 260 were reviewed in full text, and 28 were included: 20 investigating gastroesophageal reflux disorders (GERD), 3 musculoskeletal chest pain, and 5 psychiatric conditions. Study quality was good in 15 studies and moderate in 13. GERD diagnosis was more likely with typical GERD symptoms (LR +2.70 and 2.75, LR- 0.42 and 0.78 ) than atypical GERD symptoms ( $L R+0.49, L R-2.71)$. GERD was also more likely with a positive response to a proton pump inhibitor (PPI) test (LR + 5.48, 7.13, and 8.56; LR- 0.24, 0.25 , and 0.28 ); the posterior mean sensitivity and specificity of six studies were 0.89 ( $95 \%$ credible interval, 0.28 to 1) and 0.88 ( $95 \%$ credible interval, 0.26 to 1), respectively. Panic and anxiety screening scores can identify individuals requiring further testing for anxiety or panic disorders. Clinical findings in musculoskeletal pain either had a fair to moderate $L R+$ and a poor $L R$ - or vice versa.

Conclusions: In patients with NCCP, thorough clinical evaluation of the patient's history, symptoms, and clinical findings can indicate the most appropriate diagnostic tests. Treatment response to high-dose PPI treatment provides important information regarding GERD, and should be considered early. Panic and anxiety disorders are often undiagnosed and should be considered in the differential diagnosis of chest pain.
\end{abstract}

\section{Background}

In the USA, 6 million patients present to emergency departments with chest pain each year, at an annual cost of $\$ 8$ billion $[1,2]$. In emergency departments, roughly $60 \%$ to $90 \%$ of the patients presenting with chest pain have no underlying cardiovascular disease [3-6]. The proportion of patients with cardiovascular disease may be higher in specialized units (cardiology emergency departments, cardiac care units (CCUs), intensive care units (ICUs)) [7] and lower in the primary care setting [6,8-10]. Physicians generally assume that patients with

\footnotetext{
*Correspondence: Maria.Wertli@usz.ch

Horten Center for Patient Oriented Research and Knowledge Transfer, Department of Internal Medicine, University of Zurich, Pestalozzistrasse 24, $\mathrm{CH}-8032$, Zurich, Switzerland
}

non-cardiovascular chest pain (NCCP) have an excellent prognosis after ruling out serious diseases. However, patients with NCCP have a high disease burden; most patients that seek care for NCCP complain of persisting symptoms on 4-year follow-up [11]. Furthermore, compared to patients with cardiac pain, patients with noncardiac chest pain have a similarly impaired quality of life and similar numbers of doctor visits [12].

In patients with chest pain, the diagnostic investigation focuses primarily on cardiovascular disease diagnosis and is often performed by cardiologists. Upon ruling out cardiovascular disease, only vague recommendations exist for further diagnostic investigation, often delaying diagnosis and appropriate treatment and causing uncertainty for patients [13]. Limited data are available regarding efficient

\section{Biomed Central}


diagnostic investigations for patients with NCCP. Most studies investigate gastrointestinal diseases, and extensive provocation testing has been proposed [14]. Some report that almost half of the patients with NCCP will have gastrointestinal disorders [12], while others attribute more than a third of cases to psychiatric disorders, as diagnosed by the Diagnostic and Statistical Manual of Mental Disorders, fourth edition (DSMIV). Referred pain from the spine and the chest wall are also likely substantial contributors to NCCP. Information is scarce regarding the appropriate diagnostic tests, and their sensitivity and specificity to discriminate different non-cardiac diseases.

The present systematic review aimed to identify relevant diagnostic tests for patients with NCCP, and to summarize their positive and negative likelihood ratios for underlying disease identification.

\section{Methods}

\section{Literature search and study selection}

This review, conducted in May 2012, followed the QUADAS quality assessment checklist for diagnostic accuracy studies [15]. We searched six databases (PubMed/Medline, Biosis/Biological Abstracts (Web of Knowledge), Embase (OvidSP), INSPEC (Web of Knowledge), PsycInfo (OvidSP), and Web of Science (Web of Knowledge)) using the following search terms as medical subject headings (MeSH) and other subject headings: thoracic pain, chest pain, noncardiac chest pain, atypical chest pain, musculoskeletal chest pain, esophageal chest, and thoracic spine pain. The findings were limited to studies investigating 'diagnosis', 'sensitivity and specificity', 'sensitivity specificity', or chest pain/diagnosis. We applied no limits for study setting or language; however, one potentially eligible Russian language article was excluded due to lack of language proficiency [16]. Appendix 1 depicts three detailed search strategies.

To ensure search completeness, one reviewer (MW) conducted a hand search of the last 5 years in the four journals that published most articles about patients with NCCP (Gastroenterology, Chest, Journal of the American College of Cardiology and American Journal of Cardiology). Potentially eligible references not retrieved by the systematic search in the six databases were added. Bibliographies of included studies were also searched, and potential eligible references included in the full text review.

\section{Eligibility criteria}

Eligible studies included non-screening studies on diagnostic accuracy published between 1992 and May 2012. Inclusion criteria were studies reporting on patients of 18 years and older, seeking care for NCCP. NCCP was defined as chest pain and cardiac or other vascular disease was ruled out (that is, cardiovascular disease, aortic dissection, pulmonary embolism). Exclusion criteria included studies with $<30$ patients per group due to concerns about sample size [17]. This group size was arbitrarily chosen to exclude studies with the highest risk of bias, while allowing a comprehensive literature overview. Based on the nomogram proposed by Carley et al. a sample size of more than $>150$ patients are needed to accurately assess a diagnostic test [18]; however, with this sample size cut-off, very few studies (mainly retrospective data analyses) would have been eligible.

\section{Study selection, data extraction, and synthesis}

Two reviewers (MW and KR) independently screened 6,380 references by title and abstract. Both reviewers independently reviewed the full text of 260 studies meeting the eligibility criteria. Disagreements were discussed and resolved by consensus or third party arbitration (JS). Researchers with specific language proficiencies reviewed non-English language references. When the same study was included in several publications without change in diagnostic measure, the most recent publication was chosen and missing information was added from previous publications.

All information regarding the diagnostic test, reference test, and considered differential diagnosis was extracted and grouped according to the disease investigated. The methods used to assess accuracy, sensitivity, and specificity were also extracted.

\section{Quality assessment}

Study quality was assessed using the Scottish Intercollegiate Guidelines Network (SIGN) methodology checklist for diagnostic studies [19]. Overall bias risk and study quality was rated according to the SIGN recommendations. The ratings included high quality $(++$; most criteria fulfilled and if not fulfilled, the study conclusions are very unlikely to be altered), moderate quality (+; some criteria fulfilled and if not fulfilled, the study conclusions are unlikely to be altered), low quality (-; few or no criteria fulfilled, conclusions likely to be altered). Studies rated as low quality by both reviewers were excluded from further analysis.

\section{Reference standards and test evaluation}

Information about method validity, reliability, practicability and value for clinical practice of the reference and the standard test was extracted and critically assessed. When several reference standards were used, all measurements were extracted and used for further analysis.

\section{Statistical analysis}

Descriptive statistics were used to summarize findings across all diagnostic studies. Sensitivity, specificity, positive and negative predictive values (PPV and NPV, respectively), and positive and negative likelihood ratios (LR + and LR-, respectively) were calculated based on a $2 \times 2$ table (true/false positives, true/false negatives). Pretest probabilities (prevalence) and the positive and negative 
post-test probability of the disease were calculated. If one field contained the value $0,0.5$ was added to each field to enable value calculation. Test diagnostic accuracy was assessed as follows [20]: very good $(\mathrm{LR}+>10$, LR $-<0.1)$; good $(\mathrm{LR}+5$ to 10 , LR- 0.1 to 0.2$)$; fair $(\mathrm{LR}+2$ to 5 , LR0.2 to 0.5 ); or poor (LR +1 to 2 , LR- 0.5 to 1 ).

When more than four unbiased studies were available in clinically similar populations and with comparable index and reference tests, we performed joined metaanalysis of the diagnostic test sensitivity and specificity. We used a hierarchical Bayesian model, as proposed by Rutter and Gatsonis [21], which accounts for the withinstudy and between-study variability and the potentially imperfect nature of the reference test. The hierarchical Bayesian model was set up as follows: we assumed $J$ diagnostic studies in the meta-analysis, with crosstabulation between index test (T1) and reference test (T2) available for each study, and both tests assumed to be dichotomous $(1=$ positive test result, $0=$ negative test result). Each study was assumed to use a different cut-off value $\left(\theta_{\mathrm{j}}\right)$ to define a positive test result. The diagnostic accuracy of each study was denoted by $\alpha_{j}$. The model structure implied a within-study level for study-specific parameters $\left(\theta_{j}\right.$ and $\left.\alpha_{j}\right)$, and a between-study level for parameters common among all studies. The model could theoretically be extended to include study-specific covariates such as percentage of female patients or mean age to reduce heterogeneity on study level.

Appendix 2 gives details of the model set up and prior distributions. The results of the Bayesian analysis are samples from the posterior distribution of the parameters, and estimates are presented as posterior means (50\% quantile), and lower (2.5\% quantile) and upper (97.5\% quantile) bounds, resulting in a 95\% credible region. Analyses were performed using $\mathrm{R}$ statistical software and the 'HSROC' package [22,23].

\section{Ethics statement}

For this study no ethical approval was required. No protocol was published or registered. All methods were determined a priori.

\section{Results}

\section{Study selection}

Figure 1 summarizes the search and inclusion process. Out of 6380 records, 260 were reviewed in full text, resulting in exclusion of 232 studies. In total, the analysis included 28 studies. The reasons for exclusion of the 232 studies are given in Figure 1 and overview of excluded studies reviewed in full text is give in Appendix 3.

\section{Study characteristics}

Table 1 presents the study characteristics, and included patients. In all, 20 studies (71\%) evaluated diagnostic tests to identify gastrointestinal disease, mainly gastroesophageal reflux disorders (GERD), underlying NCCP. Musculoskeletal chest pain was investigated in three studies (11\%), and psychiatric conditions in five studies (18\%). Study quality was good in 15 studies (54\%) and moderate in 13 (46\%; Appendix 4). No study had to be excluded because of poor study quality.

\section{Accuracy of symptoms for the diagnosis of GERD}

Table 2 summarizes the diagnostic accuracy of the diagnostic tests relevant for clinical practice. A comprehensive overview of all evaluated diagnostic tests is provided in Appendix 5. For diagnosis of GERD, the most common reference tests (endoscopy and/or 24-h pH-metry) are reported.

Patients with the main complaint of NCCP were less likely to have GERD $(\mathrm{LR}+0.83,0.43$; LR- 1.13, 1.23) compared to patients with the main complaint of dysphagia $(L R+1.27,1.16$; LR- $0.97,0.97)$ or GERD typical symptoms without chest pain $(\mathrm{LR}+1.26,1.53$; LR- 0.93 , 0.74 ) in two studies [25,26]. Two further studies compared the accuracy of NCCP and typical GERD symptoms (LR + 2.70 [27], 2.75 [24]; LR- 0.42 [24], 0.78 [27]) with NCCP without GERD symptoms (LR + 0.49; LR2.71 [24]) or with NCCP and a history of heart burn $(\mathrm{LR}+2.15$; LR- 0.74 [27]).

\section{Accuracy of response to proton pump inhibitor (PPI) treatment for diagnosis of GERD in NCCP}

The effect of treatment with PPI was measured by using a symptom intensity score (SIS) at baseline and follow-up. The SIS was calculated by adding the reported daily severity $($ mild $=1$; moderate $=2$; severe $=3$; and disabling $=4$ ) multiplied by the reported daily frequency values obtained during each week of symptom recording.

Table 2 summarizes the results. Three studies compared the treatment response after high doses of PPI (rabeprazole [31], lansoprazole [32], omeprazole [33]) for 1 week to placebo. A reduction of the SIS score of $\geq 50 \%$ was associated with a good LR + and a fair LR- $(\mathrm{LR}+5.48$ [33], 7.13 [31], 8.56 [32]; LR- 0.24 [32], 0.25 [33], 0.28 [31]) for the presence or absence of GERD. The likelihood ratios in the placebo groups with a reduction of the SIS score of $\geq 50 \%$ were: $\mathrm{LR}+$ 0.89 [31], 0.61 [32], 3.04 [33]; LR- 1.03 [31], 1.22 [32], 0.84 [33]. A reduction of the SIS score of $\geq 65 \%$ resulted in a very good $L R+(18.33)$, and a good LR(0.17) [32]. A treatment duration of 4 weeks (lasoprazole) resulted in a better $L R-(L R+2.75$; LR- 0.13) [36] when compared to 2 weeks (omeprazole [34], LR + 2.7; LR- 0.15).

For joint meta-analysis only studies were considered with similar study design. Therefore, the active treatment arms of six studies were available for further 


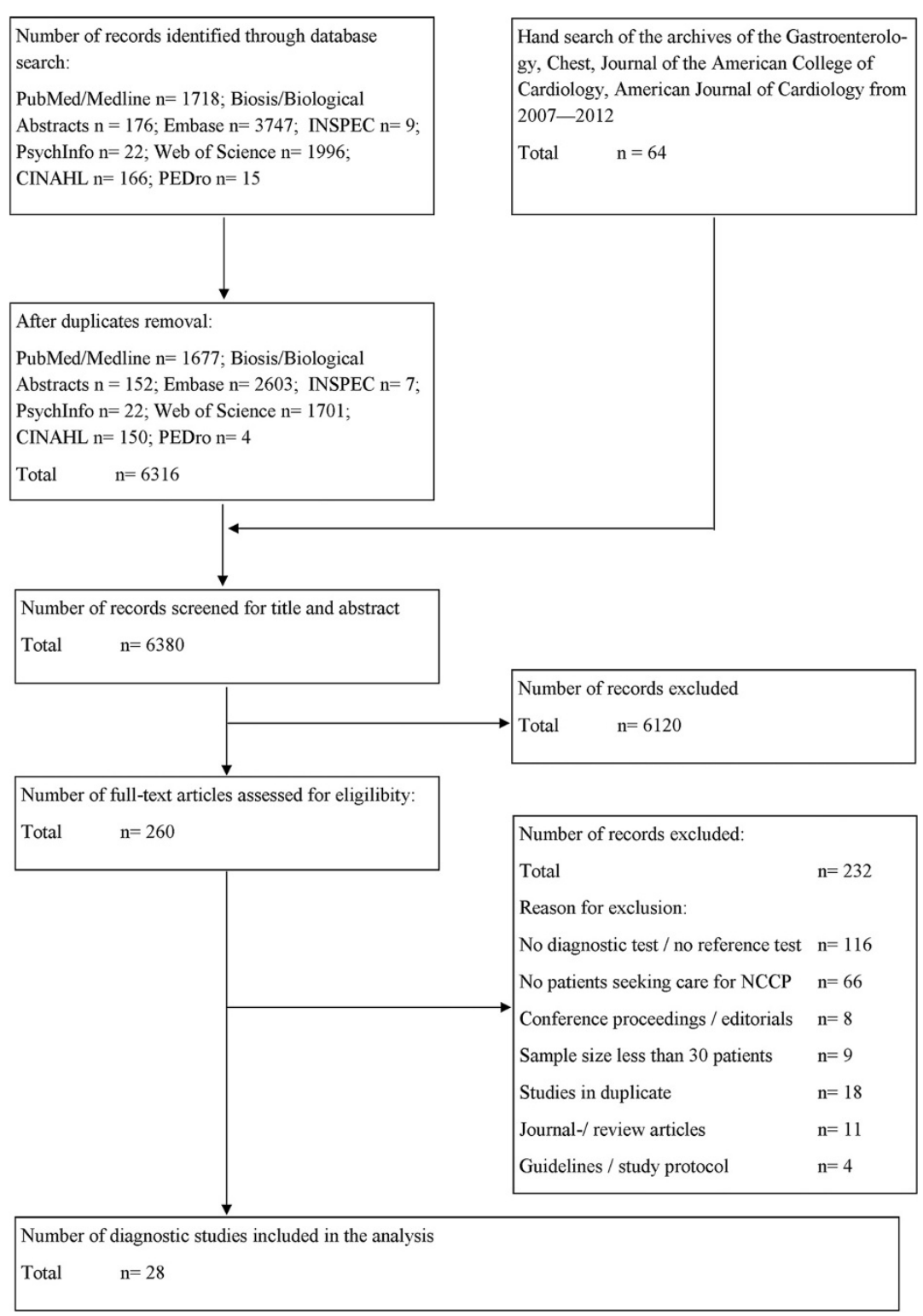

Figure 1 Study flow.

analysis [31-36]. The model could be extended to include study-specific covariates such as the percentage of female patients or mean age to reduce unexplained heterogeneity on study level. However, due to the small number of studies available for pooling we refrained from including covariates. Figure 2 shows the summary receiver operating characteristic (ROC) curve. Considering the GERD prevalence and the fact that no perfect reference test is available for GERD (sensitivity of the 24-h pH-metry in endoscopy-negative patients $<71 \%$ [57]), the posterior mean sensitivity of what was 0.89 (95\% credible interval, 0.28 to 1 ). The posterior mean of the specificity was 0.88 ( $95 \%$ credible interval, 0.26 to 1 ), respectively.

\section{Accuracy of provocation tests for GERD diagnosis}

Using a treadmill test during the 24-h pH-metry (reference test) showed highest LR + for GERD when chest pain was provoked by exercise (LR + 14.4; LR- 0.79 [39]). In all patients who underwent treadmill test, a high number of false negative test results during the treadmill test were observed.

For joint meta-analysis only studies were considered with similar study design, again. Five patient groups from four original studies were included in the analysis [38-41]. Figure 3 shows the summary ROC curve. Considering the prevalence and imperfect nature of the reference test, posterior mean sensitivity and specificity were 0.53 (95\% credible interval, 0.02 to 1 ) and 0.93 (95\% credible interval, 


\section{Table 1 Baseline characteristic of the studies}

\section{Author Study design Recruitment}

Inclusion criteria

Exclusion criteria

$\mathrm{n}$ all (n female)

Age, mean

Disease

Symptoms suggesting gastroesophageal reflux (GERD)-related non-cardiac chest pain (NCCP)

Kim et al., Cross-sectional, Inpatients with NCCP, referred by a NCCP was defined when patients 2007 [24] funding NR

cardiologist after negative cardiac evaluation. Tertiary care, Seoul, Korea.

were admitted for chest pain to the coronary unit for $\geq 1$ episode of unexplained chest pain/week for $\geq 3$ months. Cardiac chest pain was ruled out by

electrocardiogram (ECG), normal enzymes, negative treadmil exercise testing, normal or insignificant ECG changes after intravenous ergonovine injection in coronary angiograms.

Hong et al., Retrospective data 2005 [25] analysis, funding NR

Patients with a clinical suspicion of Patients with suspicion of esophageal motility abnormalities esophageal motility abnormalities and pathological acid exposure within 1 month were included in this analysis. Tertiary care, Seoul, Korea. and pathological acid exposure. NCCP was defined as recurrent angina-like or substernal chest pain believed to be unrelated to the heart, after comprehensive evaluation by the cardiologist.

First-time referrals to esophageal function testing laboratory. Tertiary care, Bern, Switzerland.

First-time referrals to esophageal function testing laboratory. NCCP group included all patients referred for $\mathrm{Gl}$ testing because of NCCP. Additional information was obtained by contacting the general practitioner (GP) and interviews.

Mousavi et al., Prospective 2007 [27] observational, funding NR

Outpatient referral by cardiologist after non-invasive diagnostic evaluation and exclusion of a cardiac or other source. Semnan, Iran.

Patients with NCCP referred to the gastrointestinal clinic. NCCP was diagnosed when chest pain was believed to be unrelated to the heart after an evaluation by a cardiologist including non-invasive testing and no apparent other diagnosis was present.

Obstructive lesions, previous esophageal balloon dilatation, botulism toxin injection, or antireflux surgery. No complaints associated with symptoms centered on the esophagus. Connective tissue diseases

\section{NR}

NCCP with GERD

$54.6(10.4)$ symptoms (sy) 24, surgery, connective tissue disorder NCCP without and chest pain originating in a GERD sy 34

musculoskeletal disorder.

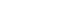

303 (female 145), 50 (15)

GERD 143,

dysphagia 56,

NCCP 45

Non-steroidal anti-inflammatory drug (NSAID) use, peptic stricture duodenal/gastric ulcer. History of upper Gl surgery, scleroderma, dia-
betes mellitus, neuropathy, myopbetes mellitus, neuropathy, myop-
athy or functional bowel disorders, athy or functional bowel disorders,
any condition that may affect lower esophageal sphincter pressure or decrease acid clearance time.

78 (female 37), NCCP with GERD sy. 35, NCCP

3 to 30 days (mean $9.3 \pm$ 4.2 days) analyzed in comparison to reflux evaluation of upper gastrointestinal patients for findings in upper complaints. Alabama, USA. gastrointestinal endoscopy and 
Table 1 Baseline characteristic of the studies (Continued)

\begin{tabular}{|c|c|c|c|}
\hline $\begin{array}{l}\text { Ho et al., } 1998 \\
\text { [29] }\end{array}$ & $\begin{array}{l}\text { Cross-sectional, } \\
\text { research grant, } \\
\text { National University of } \\
\text { Singapore }\end{array}$ & $\begin{array}{l}\text { Outpatient referral for NCCP to the } \\
\text { gastroenterology service. Tertiary } \\
\text { care, Singapore. }\end{array}$ & $\begin{array}{l}\text { Recurrent NCCP } \geq 3 \text { months. } \\
\text { Normal cardiac evaluation (non- } \\
\text { obstructed coronary arteries ( }<50 \% \\
\text { diameter narrowing), dobutamine } \\
\text { stress echocardiography, exercise } \\
\text { ECG). Cardiologist evaluation not } \\
\text { cardiac. }\end{array}$ \\
\hline $\begin{array}{l}\text { Lam et al., } \\
1992 \text { [30] }\end{array}$ & $\begin{array}{l}\text { Cross-sectional, } \\
\text { funding NR }\end{array}$ & $\begin{array}{l}\text { Patients referred to the } \\
\text { gastroenterologist after being } \\
\text { released from a cardiac care unit } \\
\text { (CCU) where they were admitted } \\
\text { with suspected myocardial } \\
\text { infarction but negative cardiac } \\
\text { evaluation. Secondary care, } \\
\text { Haarlem, The Netherlands. Patients } \\
\text { were eligible for the study when a } \\
\text { cardiologist determined the chest } \\
\text { pain to be of non-cardiac origin. }\end{array}$ & $\begin{array}{l}\text { Episode of acute, prolonged } \\
\text { retrosternal chest pain. Cardiac } \\
\text { chest pain was ruled out when no } \\
\text { abnormalities on admission ECG, } \\
\text { negative results on heart enzyme } \\
\text { tests, negative exercise test. } \\
\text { Further cardiac testing (coronary } \\
\text { angiography) was only performed } \\
\text { when considered necessary by the } \\
\text { cardiologist. }\end{array}$ \\
\hline
\end{tabular}

Studies investigating the efficacy and diagnostic value of proton pump inhibitor (PPI) trials in GERD-related NCCP

Dickman et al., Randomized, Outpatient referral by a cardiologist NCCP $\geq 3$ episodes/week (angina2005 [31] controlled trial (RCT), after negative cardiac evaluation. like) for $\geq 3$ months. Normal/ double-blind, cross- Tertiary care, Arizona, USA. insignificant findings coronary over, Janssen Pharma-

No history of esophageal disorder 61 (NR)

$\geq 3$ months or esophageal surgery ceutica und Eisai Inc.

Bautista et al. RCT, double-blind,

2004 [32] crossover, TAP

Pharmaceuticals

Fass et al. 1998 RCT, double-blind,

[33] crossover, Astra-

Merck research grant Tertiary care, Arizona, USA.

Pandak et al., RCT, double-blind,

2002 [34] crossover, Astra Zeneca

\section{Kim et al., $\quad$ Prospective}

2009 [35] observational, Janssen Pharmaceuticals after negative cardiac evaluation. Tertiary care, Arizona, USA.

Patients presented with recurrent chest pain, whose chest pain was determined by cardiologist to be of non-cardiac origin with the aid of methoxyisobutylisonitrile (MIBI) testing. Tertiary care, Arizona, USA patients referred after negative cardiac examination by cardiologists to gastroenterology. after negative cardiac evaluation. $\quad \geq 3$ months. Normal/insignificant

Outpatient referral by a cardiologist

$\mathrm{N} C \mathrm{~m} \geq 3$ episodes (angina-like) for
Normal/insignificant findings coronary angiogram, or insufficient evidence for IHD in non-invasive tests.

Outpatient referral by a cardiologist NCCP $\geq 3$ episodes (angina-like) for findings coronary angiogram, or insufficient evidence for $1 H D$ in insufficient evidence fo
non-invasive tests.

Unexplained recurrent chest pain determined to be of non-cardiac origin by a cardiologist and had Tertiary care, Seoul, Korea. were admitted for chest pain to the coronary unit for $\geq 1$ episod of unexplained chest pain/week angiogram, or insufficient evidence for ischemic heart

disease (IHD) in non-invasive tests. negative results on MIBI testing

severe comorbidity, previous empirical anti-reflux regimen, history of peptic ulcer disease or gastrointestinal surgery

Severe comorbidity, previous empirical anti-reflux regimen, history of peptic ulcer disease or gastrointestinal surgery

Previous empirical anti-reflux regimen, history of peptic ulcer disease or gastrointestinal surgery

Previous empirical anti-reflux regimen, gastric or duodenal ulcer, prior gastric surgery, abnormalities on physical exam or chest $x$-ray that would explain the chest pain

NCCP was defined when patients Severe comorbidity, history of for $\geq 3$ months. Cardiac chest pain was ruled out by ECG, norma enzymes, negative treadmi

\section{peptic ulcer disease or}

gastrointestinal surgery, history of

connective tissue disorder and

chest pain originating from

musculoskeletal disorder
41 (female 41) 61.4 (range 40 Acute

$$
\text { to } 75 \text { ) episode of }
$$

chest pain

35 (female 12),

$55.6(10.10)$

$\geq 3$ months GERD- $19(54.3 \%)$

40 (female 9),

placebo 40 , GERD

+18, GERD- 22

37 (female 1),

GERD + 23, GERD-

14

42 (female 24),

Range 22 to

$\geq 6$ months GERD + 20, GERD- 77

42 (female 17) GERD + 16, GERD-

$53.9(12.8)$

$\geq 3$ months: $n=123$ to 12 months; $\mathrm{n}=231$ to 5 years; $\mathrm{n}=7$ $>5$ years 


\begin{tabular}{|c|c|c|c|c|c|c|c|}
\hline & & & $\begin{array}{l}\text { exercise testing, normal or } \\
\text { insignificant ECG changes after } \\
\text { intravenous ergonovine injection } \\
\text { in coronary angiograms. }\end{array}$ & & & & \\
\hline $\begin{array}{l}\text { Xia et al., } 2003 \\
{[36]}\end{array}$ & $\begin{array}{l}\text { RCT, single blind, } \\
\text { Simon KY Lee } \\
\text { Gastroenterology } \\
\text { Research Fund }\end{array}$ & $\begin{array}{l}\text { Referred by a cardiologist after } \\
\text { negative cardiac evaluation. } \\
\text { Tertiary care, Hong Kong, China. }\end{array}$ & $\begin{array}{l}\text { NCCP } \geq 12 \text { weeks during last } \\
12 \text { months. Normal coronary } \\
\text { angiograph, chest pain considered } \\
\text { by a cardiologist to be NCCP. }\end{array}$ & $\begin{array}{l}\text { Pathologic endoscopic finding, } \\
\text { previous anti-reflux regimen, appar- } \\
\text { ent heartburn, acid reflux, dyspha- } \\
\text { gia and dyspepsia }\end{array}$ & $\begin{array}{l}68 \text { (female 42), } \\
\text { placebo } 32, \\
\text { lansoprazole } 36\end{array}$ & $58.2(10.0)$ & $\geq 12$ weeks \\
\hline $\begin{array}{l}\text { Kushnir et al., } \\
2010[37]\end{array}$ & $\begin{array}{l}\text { Retrospective data } \\
\text { analysis, Mentors in } \\
\text { Medicine, } \\
\text { Washington } \\
\text { University, St Louis, } \\
\text { MO, USA }\end{array}$ & $\begin{array}{l}\text { Outpatients referred for ambulatory } \\
\mathrm{pH} \text { monitoring for the evaluation } \\
\text { of unexplained chest pain. Tertiary } \\
\text { care, Missouri, USA. }\end{array}$ & $\begin{array}{l}\text { Unexplained chest pain. Cardiac } \\
\text { causes were excluded in all } \\
\text { instances before referral. }\end{array}$ & $\begin{array}{l}\text { Anti-reflux surgery in the past, } \\
\text { chest pain was not the dominant } \\
\text { symptom, pH manometry data } \\
\text { incomplete }\end{array}$ & 98 (female 75) & $51.8(1.1)$ & $\begin{array}{l}7.4 \pm \\
4.1 \text { years }\end{array}$ \\
\hline $\begin{array}{l}\text { Lacima et al. } \\
2003[38]\end{array}$ & $\begin{array}{l}\text { Cross-sectional, } \\
\text { funding NR }\end{array}$ & $\begin{array}{l}\text { Referred by a cardiologist after } \\
\text { negative cardiac evaluation. } \\
\text { Barcelona, Spain. }\end{array}$ & $\begin{array}{l}\text { Normal ECG, cardiac enzymes, } \\
\text { treadmill exercise testing, coronary } \\
\text { angiography and epicardial } \\
\text { coronary arteries or with }<25 \% \\
\text { narrowing, no ECG changes after } \\
\text { intravenous ergonovine injection }\end{array}$ & $\begin{array}{l}\text { Previous anti-reflux regimen, cal- } \\
\text { cium channel blockers, beta } \\
\text { blockers and/or nitrates were with- } \\
\text { drawn at least } 7 \text { days before the } \\
\text { study }\end{array}$ & $\begin{array}{l}120 \text { (female 62), } \\
\text { patients } 90, \\
\text { volunteers } 30\end{array}$ & 57 (27 to 82$)$ & NR \\
\hline \multicolumn{8}{|c|}{ Studies investigating the value of provocation tests for the diagnosis of GERD-related NCCP } \\
\hline $\begin{array}{l}\text { Cooke et al., } \\
1994[39]\end{array}$ & $\begin{array}{l}\text { Cross-sectional, } \\
\text { funding NR }\end{array}$ & $\begin{array}{l}\text { Patients in whom coronary } \\
\text { angiography was performed for } \\
\text { the diagnosis of new chest pain. } \\
\text { Secondary care, London, UK. }\end{array}$ & $\begin{array}{l}\text { New chest pain and normal } \\
\text { coronary anatomy with exertional } \\
\text { pain as principal complaint }\end{array}$ & $\begin{array}{l}\text { Mitral valve prolapse, left } \\
\text { ventricular hypertrophy, previous } \\
\text { myocardial infarction, abnormalities } \\
\text { of resting wall motion on } \\
\text { echocardiography, pain at rest } \\
\text { only, unable to exercise. Previous } \\
\text { anti-reflux regimen, previous } \\
\text { gastroenterologist assessment. }\end{array}$ & $\begin{array}{l}66 \text { (female 34), } \\
\text { non-cardiovascular } \\
\text { disease (CVD) 50, } \\
\text { CVD } 16 \text { (controls) }\end{array}$ & $\begin{array}{l}53 \text { (non-CVD), } \\
\text { CVD } 58 \text {, range } \\
32 \text { to } 72\end{array}$ & 3.4 years \\
\hline $\begin{array}{l}\text { Bovero et al., } \\
1993[40]\end{array}$ & $\begin{array}{l}\text { Cross-sectional, } \\
\text { funding NR }\end{array}$ & $\begin{array}{l}\text { Patients investigated for chest pain. } \\
\text { Secondary care, Genova, Italy. }\end{array}$ & $\begin{array}{l}\text { Chest pain, no coronaroactive } \\
\text { drugs for } \geq 5 \text { days. No anti-reflux } \\
\text { regimen } \geq 3 \text { days. }\end{array}$ & $\begin{array}{l}\text { Chest pain of organic and/or } \\
\text { functional cardiologic origin } \\
\text { (evaluated by: ECG, two ergometry } \\
\text { tests, dynamic ECG, thallium } \\
\text { myocardial scintigraphy under } \\
\text { physical stress or echodypiridamole } \\
\text { test, ergonovine or methyl- } \\
\text { ergometrine test, angiography) }\end{array}$ & $\begin{array}{l}67 \text { (female } 43), \\
\text { pain at rest } 46, \\
\text { exertional pain } 21\end{array}$ & $\begin{array}{l}53 \text { (range } 34 \\
\text { to } 76 \text { ) }\end{array}$ & NR \\
\hline $\begin{array}{l}\text { Romand et al., } \\
1999[41]\end{array}$ & $\begin{array}{l}\text { Cross-sectional, } \\
\text { funding NR }\end{array}$ & $\begin{array}{l}\text { Referred after negative cardiac } \\
\text { evaluation. Secondary care, Lyon, } \\
\text { France. }\end{array}$ & $\begin{array}{l}\text { Normal coronary anatomy, normal } \\
\text { ECG, negative treadmill exercise }\end{array}$ & $\begin{array}{l}\text { Cardiologic origin of symptoms, } \\
\text { history of upper gastrointestinal } \\
\text { surgery, duodenal or gastric ulcer, } \\
\text { peptic stricture or stricture by a } \\
\text { tumor }\end{array}$ & 43 (female 19) & $\begin{array}{l}56 \text { (range } 31 \\
\text { to } 78 \text { ) }\end{array}$ & $\begin{array}{l}\mathrm{n}=25 \\
<1 \text { year; } \mathrm{n}=7 \\
1 \text { to } 5 \text { years; } \\
\mathrm{n}=11 \\
>5 \text { years }\end{array}$ \\
\hline $\begin{array}{l}\text { Abrahao et al., } \\
2005[42]\end{array}$ & $\begin{array}{l}\text { Cross-sectional, } \\
\text { funding NR }\end{array}$ & $\begin{array}{l}\text { Referred by a cardiologist after } \\
\text { negative cardiac evaluation. } \\
\text { Tertiary care, Rio de Janeiro, Brazil. }\end{array}$ & $\begin{array}{l}\geq 1 \text { episode of NCCP/week, normal } \\
\text { coronary angiogram or with }<30 \% \\
\text { narrowing }\end{array}$ & $\begin{array}{l}\text { Chronic obstructive lung disease, } \\
\text { asthma, cardiac arrhythmia, } \\
\text { cardiomyopathy, valvular heart } \\
\text { disease }\end{array}$ & 40 (female 32) & $54.7(8.4)$ & $\begin{array}{l}\text { Mean } \\
24 \text { months } \\
\text { (range } 1 \text { to } \\
360 \text { months) }\end{array}$ \\
\hline
\end{tabular}


Table 1 Baseline characteristic of the studies (Continued)

\section{Ho et al., 1998 Cross-sectional, \\ Referred for NCCP to the}

[29] research grant from the National

University of

Singapore

Eosinophilic esophagitis-related NCCP

Achem et al., $\quad$ Retrospective data

2011 [43] analysis, funding NR

Musculoskeletal NCCP

Stochkendahl Cross-sectional,

et al., 2012 [44] Foundation

Chiropractic Researc

and Postgraduate

Education,

Government

Bosner et al. Cross-sectional with

2010 [45] 6 months follow-up federal Ministry of Education and Research grant

Manchikanti et Cross-sectional, no al., 2002 [46] funding

NCCP related to psychiatric diseases

Kuijpers et al., Cross-sectional,

2003 [47] funding NR

Florida, USA

Patients discharged form an

Consecutive recruitment of al chest pain. Private pain practice, USA. pain of

$\geq 3$ months; cardiologists

evaluation normal and symptoms

not cardiac (non-obstructed

coronary arteries ( $<50 \%$ luminal

narrowing), dobutamine stress

echocardiography, exercise ECG)

Referred for endoscopic evaluation Chest pain suspected of being

of NCCP, who had esophageal

esoph

esophagitis. Secondary care, invasive stress testing or coronary angiography)

Dysphagia (if this was the main reason for endoscopy).

Anticoagulant use. emergency cardiology department.

Acute ( $<7$ days) chest pain primary Cardiovascular disease, previous complaint. Pain in the thorax and/ percutaneous coronary

or neck. Understand Danish. Age intervention or coronary artery

18 to 75 years, resident of the

Funen County.

bypass graft: other definite cause,

inflammatory joint disease, insulin

dependent diabetes, fibromyalgia

malignant disease, apoplexy,

dementia or unable to cooperate

major osseous anomaly,

osteoporosis, pregnancy patients presenting to chest pain in a GP clinic. An independent interdisciplinary reference panel decided about the etiology of

Age $>35$ years, pain (acute or chronic) localized between Patients whose chest pain had
been investigated already and/or who came for follow-up for previously diagnosed chest pain were excluded

or to the posterio

axillary lines

Chronic thoracic pain, managed by Pain for $\geq 6$ months. Failure of one physician and undergoing diagnostic medial branch blocks. conservative management with physical therapy, chiropractic

management and drug therapy.

No radicular pattern of pain, no disc herniation on MRI

Age 18 to 90 years.

Discharged from the hospitals firstheart-aid service with a diagnosis of NCCP received an envelope
Chest pain or palpitation presenting to first-heart-aid service, hospital. Do not speak Dutch. received no cardiac explanation

$\begin{array}{ll}171 \text { (female 104), } & 59 \text { (24 to 86) } \\ 24 \text { (female } 7) & \text { normal } \\ \text { eosinophilia, 147 } & \text { histology, } 55 \\ \text { (female 97) } & \text { (21 to 81) } \\ \text { normal histology } & \text { eosinophilia }\end{array}$

302 (female 132) 52.5 (11.0)

Acute

episode,

$<7$ days

before

1,212 (female 678), All 59 (35 to Acute pain chest wall 93), CWS 58 $28.4 \%$

(35 to 90

565 (female 330)

46 (female 31)

$46(2.2)$

$\geq 6$ months, mean 86 (SD 17.2)

months

344 (female 151), HADS $\geq 8$ :

Hospital Anxiety 55.81 (13.03);

Depression Scale $\operatorname{HADS}<8$ :

(HADS) $\geq 8: 266 \quad 60.55$ (10.84)

(female 123);

HADS <8: 78

(female 28) 
Table 1 Baseline characteristic of the studies (Continued)

\begin{tabular}{|c|c|c|c|c|c|c|c|}
\hline $\begin{array}{l}\text { Demiryoguran } \\
\text { et al., } 2006 \text { [48] }\end{array}$ & $\begin{array}{l}\text { Cross-sectional, } \\
\text { funding NR }\end{array}$ & $\begin{array}{l}\text { Patients admitted to the ER and } \\
\text { discharged with a diagnosis of } \\
\text { NCCP. Ismir, Turkey. }\end{array}$ & $\begin{array}{l}\text { Cardiac chest pain ruled out. } \\
\text { Normal ECGs and low or stable } \\
\text { levels of cardiac markers. }\end{array}$ & $\begin{array}{l}\text { Unstable vital signs, uncooperative } \\
\text { and disoriented patients. } \\
\text { Established diagnoses. } \\
\text { Documented coronary artery } \\
\text { disease, history of trauma to chest } \\
\text { wall, back or abdomen within the } \\
\text { previous week. }\end{array}$ & $\begin{array}{l}157 \text { (female } 89 \text { ), } \\
\text { HADS <10: } 108 \\
\text { (female 55), HADS } \\
\text { >10: } 49 \text { (female } \\
\text { 34) }\end{array}$ & $41.6(11.7)$ & NR \\
\hline $\begin{array}{l}\text { Foldes-Busque } \\
\text { et al., } 2011 \text { [49] }\end{array}$ & $\begin{array}{l}\text { Cross-sectional, } \\
\text { Groupe } \\
\text { interuniversitaire de } \\
\text { recherche sur les } \\
\text { urgences (GIRU) and } \\
\text { Fonds de Recherche } \\
\text { en Santé du Québec }\end{array}$ & $\begin{array}{l}\text { Emergency department (ED), } \\
\text { Monday to Friday between } 8 \text { AM } \\
\text { and } 4 \text { PM. Tertiary care, Quebec, } \\
\text { Canada. }\end{array}$ & $\begin{array}{l}\text { Low-risk unexplained chest pain, } \\
\geq 18 \text { years old. English or French } \\
\text { speaking, normal serial ECG, } \\
\text { normal cardiac enzymes. }\end{array}$ & $\begin{array}{l}\text { Explained chest pain (for example, } \\
\text { ischemic, cause identifiable by } \\
\text { radiography). Medical condition } \\
\text { that could invalidate the interview } \\
\text { (for example, psychosis, } \\
\text { intoxication, or cognitive deficit), } \\
\text { any unstable condition, or any } \\
\text { trauma. }\end{array}$ & $\begin{array}{l}507 \text { (NR), } \\
\text { derivation sample } \\
201 \text { (female 101); } \\
\text { validation sample } \\
306 \text { (female 173) }\end{array}$ & $\begin{array}{l}\text { Derivation } \\
\text { condition } 54.2 \\
\text { (13.9), } \\
\text { validation } \\
\text { condition } 53.3 \\
\text { (14.4) }\end{array}$ & $N R$ \\
\hline $\begin{array}{l}\text { Fleet et al. } \\
1997 \text { [50] }\end{array}$ & $\begin{array}{l}\text { Cross-sectional, Fonds } \\
\text { de Recherché en } \\
\text { Santé Québec }\end{array}$ & $\begin{array}{l}\text { Consecutive patients presenting to } \\
\text { ambulatory walk in ED, patients } \\
\text { with or without IHD, Québec, } \\
\text { Canada }\end{array}$ & $\begin{array}{l}\text { Complaint of chest pain, } \\
\text { understand French, able to } \\
\text { complete evaluation in the ED }\end{array}$ & $\begin{array}{l}\text { Cognitive impairment, psychotic } \\
\text { state }\end{array}$ & $\begin{array}{l}\text { Derivation sample } \\
180 \text { (female 63), } \\
\text { validation sample } \\
212\end{array}$ & $\begin{array}{l}\text { Development } \\
57.6(12.6) \\
\text { validation } 56 \\
(12.2)\end{array}$ & NR \\
\hline $\begin{array}{l}\text { Katerndahl et } \\
\text { al., } 1997[51]\end{array}$ & $\begin{array}{l}\text { Cross-sectional, public } \\
\text { health and service } \\
\text { Establishment of } \\
\text { Departments of } \\
\text { Family Practice }\end{array}$ & $\begin{array}{l}\text { Presented to the GP with a chief } \\
\text { compliant of new-onset chest pain. } \\
\text { Primary care, Texas, USA. }\end{array}$ & $\begin{array}{l}\text { Adults } 18 \text { years and older, new- } \\
\text { onset chest pain, only one com- } \\
\text { plaint (chest pain) as well as those } \\
\text { with several symptoms that in- } \\
\text { cluded chest pain }\end{array}$ & $\begin{array}{l}\text { Previous investigation for chest } \\
\text { pain at the practice }\end{array}$ & 51 (NR) & $42.6(14.6)$ & New onset \\
\hline
\end{tabular}


Table 2 Summary of diagnostic accuracy of tests used in non-cardiac chest pain

\begin{tabular}{|c|c|c|c|c|c|}
\hline \multicolumn{6}{|l|}{ Author, year } \\
\hline & Evaluated test & Reference standard & Prevalence, $\%$ & LR+ & LR- \\
\hline \multicolumn{6}{|l|}{ Symptoms } \\
\hline Kim et al. [24] & NCCP with atypical GERD symptoms & $\begin{array}{l}\text { Endoscopy (LA classification) and/or } 24 \mathrm{~h} \text { pH-metry } \\
(>4 \%, \mathrm{pH}<4\end{array}$ & 24 & 0.49 & 2.71 \\
\hline Kim et al. [24] & NCCP with typical GERD symptoms & Same & 67 & 2.75 & 0.42 \\
\hline Mousavi et al. [27] & NCCP with typical GERD symptoms & $\begin{array}{l}\text { GERD if two tests positive: endoscopy (Hentzel-Dent), } \\
\text { Bernstein test, omeprazole trial }\end{array}$ & 45 & 2.70 & 0.78 \\
\hline Mousavi et al. [27] & NCCP relieved by antacid & Same & 45 & 0.51 & 3.51 \\
\hline Mousavi et al. [27] & NCCP and heartburn in past history & Same & 45 & 2.15 & 0.74 \\
\hline Mousavi et al. [27] & NCCP and regurgitation in past history & Same & 45 & 2.98 & 0.61 \\
\hline Hong et al. [25] & NCCP & $\begin{array}{l}\text { Manometry (Specler } 2001 \text { criteria) and/or } 24 \text { h pH-metry } \\
(>4 \% \mathrm{pH}<4)\end{array}$ & 43 & 0.83 & 1.13 \\
\hline Hong et al. [25] & Control: dysphagia & Same & 45 & 1.27 & 0.97 \\
\hline Hong et al. [25] & Control: GERD-typical symptoms & Same & 44 & 1.26 & 0.93 \\
\hline Netzer et al. [26] & NCCP & Manometry and/or 24 h pH-metry (>10.5\% pH <4) & 84 & 0.43 & 1.23 \\
\hline Netzer et al. [26] & Control: GERD-typical symptoms & Same & 84 & 1.53 & 0.74 \\
\hline Netzer et al. [26] & Control: dysphagia & Same & 84 & 1.16 & 0.97 \\
\hline \multicolumn{6}{|c|}{ Proton pump inhibitor (PPI) trial } \\
\hline Dickman et al. [31] & Rabeprazole 20 mg twice a day for 1 week SIS $\geq 50 \%$ & $\begin{array}{l}\text { Endoscopy (Hentzel-Dent grades) and/or } 24 \mathrm{~h} \mathrm{pH} \text {-metry } \\
(>4.2 \% \mathrm{pH}<4)\end{array}$ & 46 & 7.13 & 0.28 \\
\hline Dickman et al. [31] & Placebo for 1 week & Same & 46 & 0.89 & 1.03 \\
\hline Bautista et al. [32] & Lansoprazole 60 mg AM, 30 mg PM for 1 week SIS $\geq 50 \%$ & $\begin{array}{l}\text { Endoscopy (Hentzel-Dent grades) and/or } 24 \mathrm{~h} \mathrm{pH} \text {-metry } \\
(>4.2 \% \mathrm{pH}<4)\end{array}$ & 45 & 8.56 & 0.24 \\
\hline Bautista et al. [32] & Lansoprazole 60 mg AM, 30 mg PM for 1 week SIS $\geq 65 \%$ & Same & 45 & 18.33 & 0.17 \\
\hline Bautista et al. [32] & Placebo for 1 week & Same & 45 & 0.61 & 1.22 \\
\hline Fass et al. [33] & Omeprazole 40 mg AM, 20 mg PM for 1 week SIS $\geq 50 \%$ & $\begin{array}{l}\text { Endoscopy (Hentzel-Dent grades) and/or } 24 \mathrm{~h} \mathrm{pH} \text {-metry } \\
(>4.2 \% \mathrm{pH}<4)\end{array}$ & 62 & 5.48 & 0.25 \\
\hline Fass et al. [33] & Placebo for 1 week & Same & 62 & 3.04 & 0.84 \\
\hline Pandak et al. [34] & Omeprazole 40 mg twice a day for 2 weeks SIS $\geq 50 \%$ & Endoscopy and/or $24 \mathrm{~h} \mathrm{pH}$-metry $(>4.2 \% \mathrm{pH}<4)$ & 53 & 2.70 & 0.15 \\
\hline Pandak et al. [34] & Placebo for 2 weeks SIS $\geq 50 \%$ & Same & 53 & 0.30 & 1.14 \\
\hline Kim et al. [35] & NCCP rabeprazole for 1 week SIS $\geq 50 \%$ & $\begin{array}{l}\text { Endoscopy (LA classification) and/or } 24 \mathrm{~h} \text { pH-metry } \\
(>4.0 \mathrm{pH}<4)\end{array}$ & 38 & 2.17 & 0.65 \\
\hline Kim et al. [35] & NCCP rabeprazole for 2 weeks SIS $\geq 50 \%$ & Same & 38 & 3.02 & 0.26 \\
\hline Xia et al. [36] & Lansoprazole $30 \mathrm{mg}$ once a day for 4 weeks SIS $\geq 50 \%$ & $24 \mathrm{~h}$ pH-metry (De Meester $\mathrm{pH}<4,7.5 \mathrm{~s}$ ) & 33 & 2.75 & 0.13 \\
\hline Xia et al. [36] & Placebo for 4 weeks SIS $\geq 50 \%$ & Same & 38 & 0.95 & 1.03 \\
\hline
\end{tabular}


Table 2 Summary of diagnostic accuracy of tests used in non-cardiac chest pain (Continued)

\begin{tabular}{|c|c|}
\hline Kushnir et al. [37] & High-degree response on PPI (not specified) \\
\hline \multicolumn{2}{|l|}{ Provocation test } \\
\hline Cooke et al. [39] & NCCP during exertional pH-metry \\
\hline Cooke et al. [39] & Control group: CVD with angina: exertional pH-metry \\
\hline Bovero et al. [40] & NCCP with normal ECG during exertional pH-metry \\
\hline Bovero et al. [40] & NCCP at rest: NCCP with normal ECG during exertional pH-metry \\
\hline Bovero et al. [40] & NCCP exertion/mixed: NCCP with normal ECG during exertional pH-me \\
\hline Romand et al. [41] & NCCP: $\mathrm{pH}<4$ for $10 \mathrm{~s}$ during exertional pH-metry \\
\hline Abrahao et al. [42] & NCCP reproducible during balloon distension \\
\hline Abrahao et al. [42] & NCCP reproducible during Tensilon test \\
\hline Abrahao et al. [42] & NCCP reproducible during Bernstein test \\
\hline Abrahao et al. [42] & Tensilon and Bernstein Test and balloon distension ( + if 1 test + ) \\
\hline Ho et al. [29] & NCCP reproducible during Bernstein test \\
\hline \multicolumn{2}{|l|}{ Musculoskeletal disorders } \\
\hline Stochkendahl et al. [44] & $\begin{array}{l}\geq 3 \text { of } 5 \text { palpation findings: (1) sitting motion of end-play restriction in } \\
\text { lateral flexion and rotation segment C4 to C7 and Th1 to Th8. (2) } \\
\text { Prone motion joint-play restriction segment Th1 to Th8. (3) Prone } \\
\text { evaluation paraspinal tenderness segment Th1 to Th8. (4) Supine } \\
\text { manual palpation muscular tenderness of } 14 \text { points anterior chest } \\
\text { wall. 5) Supine evaluation of tenderness of the costosternal } \\
\text { junctions of costa } 2 \text { to } 6 \text { and xiphoid process }\end{array}$ \\
\hline
\end{tabular}

Bosner et al. [45]

Bosner et al. [45]

Stochkendahl et al. [44]

Stochkendahl et al. [44]

stinging pain, pain reproducible by palpation, absence of cough

Cut-off test negative 0 to 1 points

reproducible by palpation, absence of cough examination protocol)
$24 \mathrm{pH}$-metry $(\geq 4 \%, \mathrm{pH}<4)$

1.97

$24 \mathrm{~h} \mathrm{pH}$-metry $(5.5 \% \mathrm{pH}<4$ for $10 \mathrm{~s})$

Same

$24 \mathrm{~h} \mathrm{pH}$-metry (De Meester criteria: $>4.5 \% \mathrm{pH}<4$ ))

Same

Same

$24 \mathrm{~h} \mathrm{pH}$-metry (De Meester criteria: >4.5\% pH <4))

Endoscopy (Savary-Miller) and/or manometry and/or pH-metry (De Meester criteria: $>4.5 \% \mathrm{pH}<4$

Same

Same

Same

$24 \mathrm{~h}$ pH-metry $(>4 \% \mathrm{pH}<4,4$ s)

Diagnosis using a standardized examination protocol:

(1) A semistructured interview: pain characteristics, lung and gastrointestinal symptoms, past medical history,

height, weight, cardiovascular risk factors

(2) A general health examination: blood pressure, pulse, heart and lung stethoscopy, abdominal palpation, neck heart and lung ste hoscopy, abdominal passure, puseck auscultation, signs of left ventricular failure, neurologica

(3) Manual examination of the muscles and joints (neck thoracic spine and thorax): active range of motion

manual palpation 14 points muscular tenderness of the anterior chest wall and segmental paraspinal muscles, motion palpation for joint-play restriction of the thoraci spine (Th1 to 8), and end play restriction of the cervical and thoracic spine

Interdisciplinary consensus: cardiologist, GP, research associate (based on reviewed baseline, follow-up data at 6 weeks and 6 months)

Interdisciplinary consensus

Standardized examination protoco

Standardized examination protocol 
Table 2 Summary of diagnostic accuracy of tests used in non-cardiac chest pain (Continued)

\begin{tabular}{|c|c|c|c|c|c|}
\hline Stochkendahl et al. [44] & Angina pectoris (uncertain or negative) & Standardized examination protocol & 37 & 1.26 & 0.12 \\
\hline Stochkendahl et al. [44] & Pain worse on movement of torso & Standardized examination protocol & 37 & 3.39 & 0.78 \\
\hline Bosner et al. [45] & Pain worse with movement & Interdisciplinary consensus & 47 & 2.13 & 0.75 \\
\hline Stochkendahl et al. [44] & Positive/possible belief in pain origin from muscle/joints & Standardized examination protocol & 37 & 1.17 & 0.20 \\
\hline Stochkendahl et al. [44] & Pain relief on pain medication & Standardized examination protocol & 37 & 3.26 & 0.83 \\
\hline Bosner et al. [45] & Pain reproducible by palpation & Interdisciplinary consensus & 47 & 2.08 & 0.54 \\
\hline Stochkendahl et al. [44] & Paraspinal tenderness & Standardized examination protocol & 37 & 1.36 & 0.48 \\
\hline Bosner et al. [45] & Localized muscle tension & Interdisciplinary consensus & 47 & 2.41 & 0.52 \\
\hline Stochkendahl et al. [44] & Chest pain present now & Standardized examination protocol & 37 & 1.35 & 0.46 \\
\hline Bosner et al. [45] & Pain now & Interdisciplinary consensus & 47 & 1.15 & 0.85 \\
\hline Stochkendahl et al. [44] & Pain debut not during a meal & Standardized examination protocol & 37 & 1.10 & 0.23 \\
\hline Stochkendahl et al. [44] & Sharp pain & Standardized examination protocol & 37 & 1.89 & 0.80 \\
\hline Bosner et al. [45] & Stinging pain & Interdisciplinary consensus & 47 & 1.87 & 0.66 \\
\hline Stochkendahl et al. [44] & Hard physical exercise at least once a week & Standardized examination protocol & 37 & 1.19 & 0.91 \\
\hline Stochkendahl et al. [44] & Pain not provoked during a meal & Standardized examination protocol & 37 & 1.09 & 0.25 \\
\hline Stochkendahl et al. [44] & Not sudden debut & Standardized examination protocol & 37 & 2.90 & 0.63 \\
\hline Bosner et al. [45] & Pain $>24 \mathrm{~h}$ & Interdisciplinary consensus & 47 & 1.30 & 0.92 \\
\hline Stochkendahl et al. [44] & Age $\leq 49$ years old & Standardized examination protocol & 37 & 2.10 & 0.56 \\
\hline Bosner et al. [45] & Pain mostly at noon time & Interdisciplinary consensus & 47 & 0.50 & 1.02 \\
\hline Bosner et al. [45] & Cough & Interdisciplinary consensus & 47 & 0.28 & 1.18 \\
\hline Bosner et al. [45] & Known IHD & Interdisciplinary consensus & 47 & 0.52 & 1.11 \\
\hline Bosner et al. [45] & Pain worse with breathing & Interdisciplinary consensus & 47 & 1.28 & 0.93 \\
\hline \multicolumn{6}{|l|}{ Psychiatric diseases } \\
\hline Kuijpers et al. [47] & $\begin{array}{l}\text { Anxiety subscale of the Hospital Anxiety and Depression Scale } \\
\text { (HADS-A score, cut-off } \geq 8 \text { ) }\end{array}$ & $\begin{array}{l}\text { Diagnosis anxiety disorders (Mini International } \\
\text { Neuropsychiatric Interview (gold standard)) }\end{array}$ & 58 & 2.03 & 0.03 \\
\hline Demiryoguran et al. [48] & Chills or hot flushes & Anxiety disorder: HADS-A score (cut-off $\geq 10$ ) & 31 & 4.85 & 0.81 \\
\hline Demiryoguran et al. [48] & Fear of dying & Anxiety disorder: HADS-A score (cut-off $\geq 10$ ) & 31 & 4.04 & 0.82 \\
\hline Demiryoguran et al. [48] & Diaphoresis & Anxiety disorder: HADS-A score (cut-off $\geq 10$ ) & 31 & 3.49 & 0.69 \\
\hline Demiryoguran et al. [48] & Light-headedness, dizziness, faintness & Anxiety disorder: HADS-A score (cut-off $\geq 10$ ) & 31 & 3.03 & 0.84 \\
\hline Demiryoguran et al. [48] & Palpitation & Anxiety disorder: HADS-A score (cut-off $\geq 10$ ) & 31 & 1.54 & 0.83 \\
\hline Demiryoguran et al. [48] & Shortness of breath & Anxiety disorder: HADS-A score (cut-off $\geq 10$ ) & 31 & 1.30 & 0.92 \\
\hline Demiryoguran et al. [48] & Nausea or gastric discomfort & Anxiety disorder: HADS-A score (cut-off $\geq 10$ ) & 31 & 1.98 & 0.90 \\
\hline
\end{tabular}


Table 2 Summary of diagnostic accuracy of tests used in non-cardiac chest pain (Continued)

Foldes-Busque et al. [49] The Panic Screening Score (derivation population); does the patient ers? Please indicate how often this are nervous: 'I will choke to death'. Did the patient arrive in the ED by ambulance? Please answer the statement by circling the number that best applies to you: 'When I notice my heart beating rapidly, I worry that I might be having a heart attack'. Sum score 22, A total score $\geq 6$ indicates probable panic.

Foldes-Busque et al. [49] The Panic Screening Score (validation population).

Fleet et al. [50]

Panic disorder diagnosis: formula including Agoraphobia Cognitions QA, Mobility Inventory for Agoraphobia, Zone 12 Dermatome Pain Map, Sensory McGill Pain QA, Gender, Zone 25 (validation population)

Katerndahl et al. [51]
Panic disorder Diagnosis (structured Anxiety Disorders Interview Schedule for Diagnostic and Statistical Manual of Mental Disorders, fourth edition (DSM-IV) (ADIS-IV))

Panic disorder diagnosis (structured ADIS-IV)

Panic disorder (ADIS-R structured interview by

psychologist)

Panic disorder (structured clinical interview of Diagnostic and Statistical Manual of Mental Disorders, based on DSM-III-R)

LR+: >10; LR-: <0.1; good: LR+5 to 10, LR- 0.1 to 0.2 ; fair: $L R+2$ to 5 , LR- 0.2 to 0.5 ; poor: $L R+1$ to 2 , LR- 0.5 to 1 .

${ }^{a}$ Biomechanical dysfunction defined as chest pain presumably caused by mechanical joint and muscle dysfunction related to $C 4$ to Th8 somatic structures of the spine and chest wall established by means of joint-play and/or end-play palpation.

and/or end-play palpation. Reference tests are as follows. Endoscopic classification: LA classification: grade $A, \geq 1$ mucosal break $\leq 5 \mathrm{~mm}$, that does not extend between the tops of two mucosal folds; grade $B, \geq 1 \mathrm{mucosal}$ break $>5 \mathrm{~mm}$ long
does not extend between the tops of two mucosal folds; grade $C, \geq 1$ mucosal break that is continuous between the tops of two or more mucosal folds but which involves $<75 \%$ of the circumference; grade $D, \geq 1$ mucosal break which involves at least $75 \%$ of the esophageal circumference [52]. Savary-Miller system: grade I, single or isolated erosive lesion(s) affecting only one longitudinal fold; grade II multiple erosive lesions, mucosal break which involves at least $75 \%$ of the esophageal circumference [52]. Savary-Miller system: grade l, single or isolated erosive lesion(s) affecting only one longitudinal fold; grade II multiple erosive lesions, non-circumferential, affecting more than one longitudinal fold, with or without confluence; grade III, circumferential erosive lesions; grade I, chronic lesions: ulcer(s), stricture(s) and/or short esophagus. Alone or asso:-
ated with lesions of grades 1 to 3; grade V, columnar epithelium in continuity with the Z line, non-circular, star-shaped, or circumferential. Alone or associated with lesions of grades 1 to 4 [53]. Hentzel-Dent grades: ated with lesions of grades 1 to 3 ; grade $V$, columnar epithelium in continuity with the Z line, non-circular, star-shaped, or circumferential. Alone or associated with lesions of grades 1 to 4 [53]. Hentzel-Dent grades: grade 0 , no mucosal abnormalities; grade 1, no macroscopic lesions but erythema, hyperemia, or mucosal friability; grade 2, superficial erosions involving $<10 \%$ of mucosal surface of the last $5 \mathrm{~cm}$ of esophageal squamous mucosa; grade 3, superficial erosions or ulceration involving $10 \%$ to $50 \%$ of the mucosal surface of the last $5 \mathrm{~cm}$ of esophageal squamous mucosa; grade 4 , deep peptide ulceration anywhere in the esophagus or confluent erosion of $>50 \%$ of the mucosal surface of the last $5 \mathrm{~cm}$ of esophageal squamous mucosa [54]. pH-metry: De Meester criteria: (1) total number of reflux episodes; (2) number of reflux episodes with $\mathrm{pH}<4$ for more than 5 minutes; (3) duration of the longest episode; (4) percentage total time $\mathrm{pH}<4$; (5) percentage upright time $\mathrm{pH}<4$; and (6) percentage recumbent time $\mathrm{pH}<4$. [55]. Manometry: Spechler criteria is diagnosis of ineffective esophageal motility, nutcracker esophagus, spasm, achalasia based on basal lower esophageal sphincter pressure, relaxation, wave progression, distal wave amplitude [56].

24-h pH-metry 24-h pH monitoring, GERD gastroesophageal reflux disease, GP general practitioner, IHD ischemic heart disease, QA questionnaire, Sensory McGill McGill Pain Questionnaire sensory subscale, SIS symptom index score calculated by adding the reported daily severity (mild $=1$; moderate $=2$; severe $=3$; and disabling $=4$ ) multiplied by the reported daily frequency values during each week). 


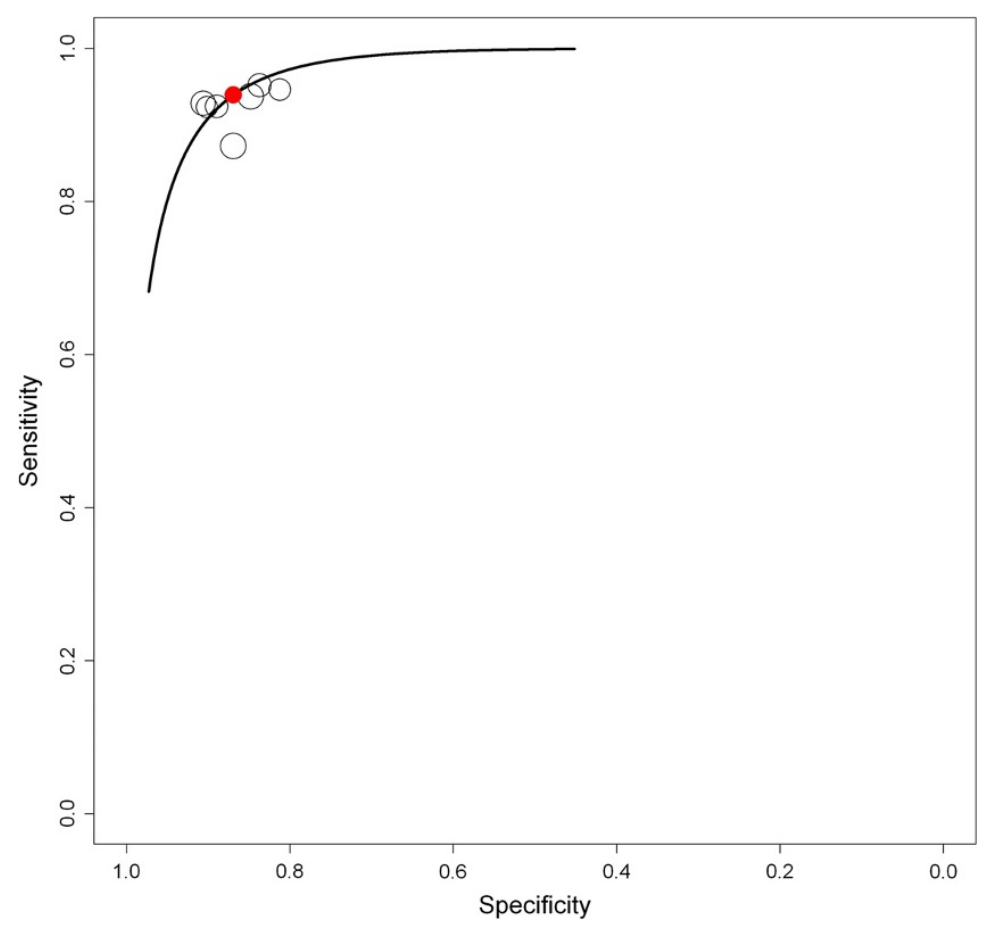

Figure 2 Summary receiver operating characteristic (ROC) curve of proton pump inhibitor (PPI) studies.

0.25 to 1 ), respectively. For all provocation tests (Tensilon test, Bernstein test, or balloon distension test) high numbers of false negative results were found $[29,42]$.

\section{Accuracy of patient characteristics for eosinophilic esophagitis diagnosis}

Eosinophilic esophagitis is a rare but important differential diagnosis for NCCP. In a retrospective analysis the likelihood for histologically proven eosinophilic esophagitis (reference test) was fair when current GERD symptoms were present $(\mathrm{LR}+2.36$, LR- 0.71 (poor)). Male gender or the presence of typical endoscopic findings for eosinophilic esophagitis were associated with a poor LR + (1.78) but a very good LR- (0.09) No information was available about eosinophilia that responds to PPI treatment compared to eosinophilic esophagitis.

\section{Accuracy of clinical signs for musculoskeletal chest pain diagnosis}

In one study in a cardiology emergency department specific clinical signs or symptoms compared to a standardized examination protocol showed either fair LR + and poor LR- (for example, pain worse with movement of the torso, pain relief on pain medication, no sudden pain start, age $\leq 49$ years) or a poor LR + and a very good LR- (for example, anterior chest wall tenderness, biomechanical dysfunction) [44]. A score of 3 or more points in a sum score (1 point for each of five palpation findings: restriction in $\mathrm{C} 4$ to $7 / \mathrm{Th} 1$ to Th8 when sitting; prone restriction Th1 to 8; paraspinal tenderness; anterior chest wall tenderness; costosternal junction tenderness) showed an LR + of 1.52 and very good LR- of 0.03 . A score of 1 or more points in a sum score for the diagnosis of a chest wall syndrome (CWS) in the GP setting (1 point for each positive finding: localized muscle tension; stinging pain; pain reproducible by palpation; absence of cough) showed a LR + of 1.82 and LR- of 0.20 [45]. A score of 2 or more points in the sum score showed a $L R+$ of 3.02 and LR- of 0.47 .

\section{Accuracy of patient characteristics for psychiatric disease diagnosis}

For the diagnosis of an anxiety disorder the anxiety subscale of the Hospital Anxiety and Depression Score (HADS-A, cut-off $\geq 8$ ) compared to a neuropsychiatric interview (reference test) showed a very good LR- (0.03) and a fair $L R+(2.03)$. In further studies the HADS-A was used as reference test for the diagnosis of anxiety disorder. Specific symptoms showed a fair $L R+$ and a poor LR-: fear of dying ( $\mathrm{LR}+4.04$; LR- 0.82); lightheadedness, dizziness, or faintness (LR + 3.03; LR- 0.84); diaphoresis (LR + 3.49; LR- 0.69); and chills or hot flushes (LR + 4.85; LR- 0.81).

For panic disorders a four-item panic screening score validated in patients presenting to an ER 


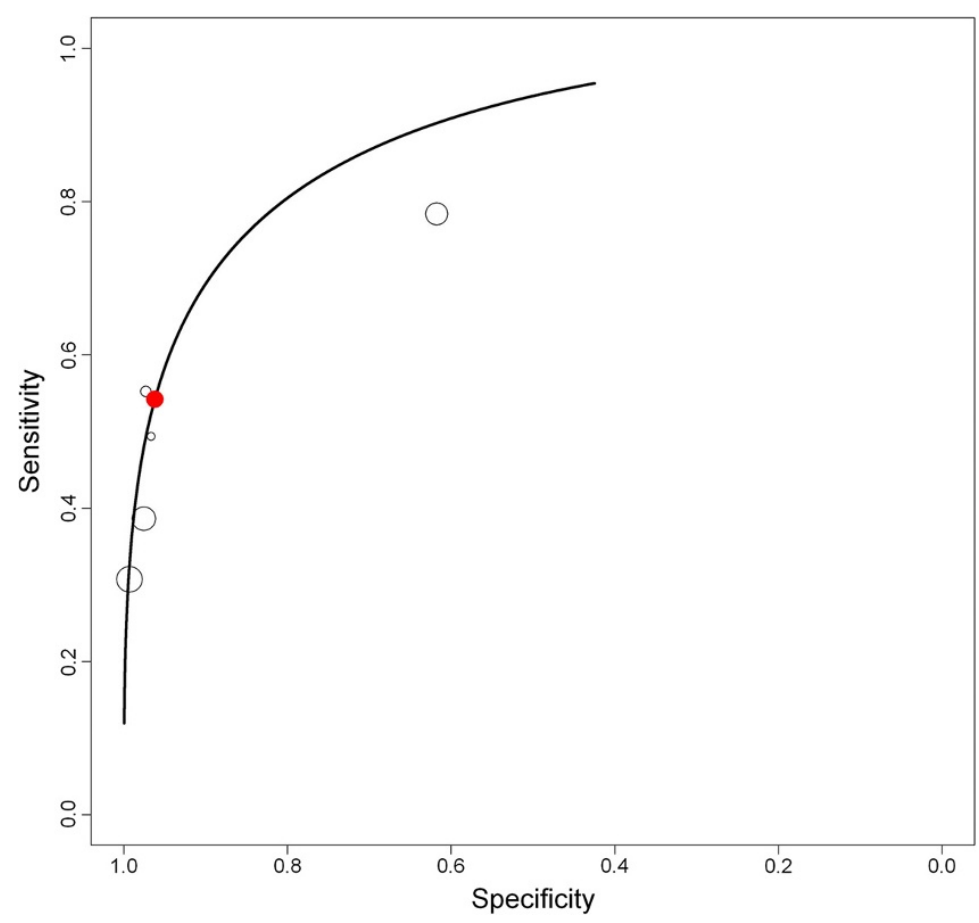

Figure 3 Summary receiver operating characteristic (ROC) for treadmill test during $24 \mathrm{~h} \mathrm{pH}-$ metry.

showed fair $L R+(3.44$ and 3.89) and poor-to-fair LR(0.44 and 0.55) [49]. A combination of different questionnaires and pain patterns (Agoraphobia Cognitions Questionnaire; Mobility Inventory for Agoraphobia; McGill Pain Questionnaire sensory) showed a fair LR $+(2.6)$ and fair LR- (0.46) [50]. In patients presenting to their primary care physician with NCCP the presence of a panic disorder was rarely diagnosed. Clinician consultations in this setting had poor accuracy for panic disorder diagnosis ( $L R+0.8$; LR- 1.02) [51].

\section{Discussion}

\section{Main findings}

The included studies showed that most studies investigated tests for gastroesophageal reflux disease (GERD) as the underlying disease in non-cardiovascular chest pain (NCCP). Few studies investigated diagnostic tests for other illnesses. The diagnostic value of a PPI treatment test was confirmed, with a $\geq 50 \%$ symptom reduction under PPI treatment showing posterior sensitivity and specificity of almost 90\%. Together with the favorable adverse effect profile of PPIs, a high dose (double reference dose, twice daily) can quickly provide important diagnostic information in patients with unexplained chest pain. History or presence of typical GERD-associated symptoms increases the likelihood of GERD.
Only limited evidence was available for other prevalent illnesses manifesting with chest pain. Screening tools for panic and anxiety disorders are valuable for identifying patients requiring further diagnostic evaluation. The likelihood for musculoskeletal chest pain increased when the pain was reproducible or relieved by pain medication. Among studies investigating musculoskeletal disease, the major limitation was the lack of a reference test ('gold standard').

\section{Results in light of existing literature}

To the best of our knowledge, this is the first systematic review summarizing the current evidence on the accuracy of diagnostic tests in patients with NCCP. Several non-systematic reviews have suggested various diagnostic and therapeutic approaches [14,58-61], often with algorithms focused on gastrointestinal diseases [14,58,59], sometimes recommending extensive testing, such as provocation tests. Here, we found no additional value of provocation testing for diagnosing underlying gastroesophageal conditions, as provocation tests failed to identify many patients that would have reflux during a 24- $\mathrm{h} \mathrm{pH}$ measurement period. While meta-analyses of PPI treatment studies compared to placebo have been previously conducted $[62,63]$, compared to this analyses we excluded studies of poor quality and small sample sizes [64-67]. Our study is the first to assess study quality and to use a 
hierarchical Bayesian approach that accounts for within-study and between-study variability and the imperfect nature of the reference test.

Cremonini et al. [62] previously used a bivariate model, and found a lower pooled sensitivity and specificity (sensitivity $80 \%$ vs $89 \%$, specificity $74 \%$ vs $88 \%$ ) of a positive PPI treatment response for the diagnosis of GERD. Harbord et al. [68] showed that the likelihood functions of the two model formulations are algebraically identical in the absence of covariates. However, for assessing a summary ROC curve, the hierarchical Bayesian model is more natural than the model for pooled sensitivity and specificity [69]. Without a broadly accepted standard reference test, it is important to adjust for conditional dependence between multiple tests (index test and reference test) carried out in the same subjects [69]. The hierarchical Bayesian model can be adapted to this situation by introducing covariance terms between the sensitivities and specificities of the index and reference tests. A previous simulation study [69] demonstrated that if a model does not address an imperfect reference test, bias will be around 0.15 in overall sensitivity and specificity [69]. No systematic review has examined diagnostic studies of musculoskeletal chest pain or chest pain as part of a psychiatric disease.

\section{Strengths and limitations}

This review comprehensively evaluates the currently available studies. The search was inclusive, no language restrictions were applied, and a thorough bibliographic search was conducted to identify all relevant studies. The extraction process was performed in accordance with current guidelines and supported by an experienced statistician. Potential factors influencing diagnostic test accuracy were identified by a multidisciplinary team (an internist, general practitioner, statistician, and methodologist).

The study was limited by the small number of studies available for most diseases presenting with NCCP. Furthermore, many studies were only of moderate quality and most cross-sectional or prospective studies did not meet the required sample size criterion for reliable estimates of sensitivity and specificity. Small studies on diagnostic accuracy are often imprecise, with wide confidence intervals, making it difficult to assess test informativeness [17]. The lack of a gold standard reference test is another limitation, which we addressed within the Bayesian model formulation; however, the resulting posterior credible intervals for overall sensitivity and specificity of the index test are wider than they would be with a perfect reference test. Further, NCCP is a collective term with potentially different underlying diseases and therefore might present differently. Diagnostic accuracy in one population with high prevalence for one disease is high might be entirely different for another population [70]. Therefore, for most studies no joint meta-analysis could be conducted and results have to be interpreted on a single study level within the context of the study population. We have tried to balance this by providing a thorough description of the studies' inclusion and exclusion criteria and the study setting. This will allow readers to judge to whom study results apply. In studies included in the joint meta-analyses, we intended to include study-specific covariates such as the percentage of female or mean age into the Bayesian model. The inclusion of covariates can reduce unexplained heterogeneity. However, this was due to the small number of studies available for meta-analysis not feasible.

\section{Research implications}

Further research should investigate the combined value of symptoms, clinical findings, and diagnostic tests, including multidisciplinary research aimed at increasing our knowledge about diagnostic processes and making recommendations for diagnostic tests and treatments in patients with NCCP. Most patients with chest pain consult primary care physicians [45], but few studies are performed in this setting. Further research is needed to strengthen the evidence in a primary care setting. The value of screening questionnaires for panic and anxiety disorders should be further evaluated and investigated in clinical practice. The use of a flag system [61], as successfully applied in back and neck pain, could facilitate the diagnostic process allowing systematic assessment of first red flags (acute disease requiring immediate diagnosis and care), then green flags (identifiable diseases), and yellow flags (psychological diseases).

\section{Implication for practice}

Patients with NCCP incur high healthcare costs due to the extensive and often invasive diagnostic testing, and NCCP's impact on quality of life. Early identification of underlying diseases is essential to avoid delayed treatment and chronicity of complaints. Symptoms and clinical findings may provide important information to guide treatment of an underlying illness. In patients with typical GERD symptoms, twice-daily high-dose PPI treatment is the most efficient diagnostic approach. GERD is very likely if a positive treatment response occurs after 1 week, while GERD is unlikely if there is no response after 4 weeks of PPI treatment. In patients not responding to PPI, if an endoscopy shows no pathological findings, other illnesses should be considered before initiating further gastrointestinal testing.

Panic and anxiety disorders are often missed in clinical practice [51]. Symptoms such as expressing 'fear of dying, 'light headedness, dizziness, faintness,' 'diaphoresis' and 'chills or hot flushes' are associated with anxiety disorders. Screening tests are valuable to rule out panic or 
anxiety disorders, and positive finding should lead to further investigation.

\section{Conclusions}

In patients with NCCP, timely diagnostic evaluation and treatment of the underlying disease is important. A thorough history of symptoms and clinical examination findings can inform clinicians which diagnostic tests are most appropriate. Response to high-dose PPI treatment can indicate whether GERD is the underlying disease and should be considered as an early test. Panic and anxiety disorders are often not diagnosed and should be considered in the differential diagnosis of chest pain.

\section{Appendix 1: Search Strategy May Week 42012}

In Tables 3 and 4 the detailed search strategy of PubMed, Web of Knowledge (INSPEC, Biosis/Biological Abstracts, Web of Science) and OvidSP (Embase, PsycInfo) are given.

\section{Biological Abstracts/BIOSIS, INSPEC and Web of Science (Web of Knowledge)}

Topic = ('thoracic pain' OR 'chest pain' OR 'noncardiac chest pain' OR 'non cardiac chest pain' OR 'atypical chest pain' OR 'musculoskeletal chest pain' OR 'esophageal chest pain' OR 'thoracic spine pain' OR 'chest wall') AND Topic $=($ sensitivity OR specificity OR diagnostic tests) NOT Topic $=($ coronary artery disease OR cardiac disease OR coronary heart disease OR coronary thrombosis OR coronary occlusion)

Refined by: Topic $=\left(\right.$ human* ${ }^{*}$

Timespan $=1992$ to 2012 .

Table 3 Search Strategy May Week 42012 (PubMed)

\begin{tabular}{|c|c|c|}
\hline No. & Search & Hits \\
\hline 1 & $\begin{array}{l}\text { Search thoracic pain OR chest pain OR noncardiac chest } \\
\text { pain OR non cardiac chest pain OR atypical chest pain } \\
\text { OR musculoskeletal chest pain OR esophageal chest } \\
\text { pain OR thoracic spine pain OR chest wall }\end{array}$ & 96,313 \\
\hline 2 & $\begin{array}{l}\text { Search coronary artery disease OR cardiac disease OR } \\
\text { coronary heart disease OR coronary thrombosis OR } \\
\text { coronary occlusion }\end{array}$ & 929,959 \\
\hline 3 & Search 1 NOT 2 & 38,735 \\
\hline 4 & $\begin{array}{l}\text { Search sensitivity OR specificity OR diagnostic tests } \\
\text { OR chest pain/diagnosis }\end{array}$ & $1,301,595$ \\
\hline 5 & Search 3 AND 4 & 2,736 \\
\hline 6 & $\begin{array}{l}\text { Search } 5 \text { NOT 2; Filters: publication date from } \\
\text { 1992/01/01; humans }\end{array}$ & 2,177 \\
\hline 7 & $\begin{array}{l}\text { Search } 5 \text { NOT 2; Filters: publication date from } \\
\text { 1992/01/01; humans; adult: 19+ years }\end{array}$ & 1,432 \\
\hline
\end{tabular}

Table 4 Database: PsycINFO <1806 to May Week 4 2012>, Embase $<1974$ to 2012 Week 21> (OvidSP)

\begin{tabular}{|c|c|c|}
\hline No. & Search & Hits \\
\hline 1 & $\begin{array}{l}\text { (thoracic pain or chest pain or noncardiac chest pain } \\
\text { or non cardiac chest pain or atypical chest pain or } \\
\text { musculoskeletal chest pain or esophageal chest pain } \\
\text { or thoracic spine pain or chest wall).mp. [mp = ti, ab, } \\
\mathrm{hw}, \mathrm{tc}, \mathrm{id}, \mathrm{ot}, \mathrm{tm}, \mathrm{sh}, \mathrm{tn}, \mathrm{dm}, \mathrm{mf}, \mathrm{dv}, \mathrm{kw}]\end{array}$ & 44,196 \\
\hline 2 & exp thorax pain/di [Diagnosis] & 2,481 \\
\hline 3 & exp thorax pain/ & 36,580 \\
\hline 4 & 1 or 3 & 63,756 \\
\hline 5 & $\begin{array}{l}\text { Coronary artery disease or cardiac disease or coronary } \\
\text { heart disease or coronary thrombosis or coronary } \\
\text { occlusion).mp. [mp = ti, ab, hw, tc, id, ot, tm, sh, tn, } \\
d m, m f, d v, k w]\end{array}$ & 222,468 \\
\hline 6 & 4 not 5 & 55,961 \\
\hline 7 & $\begin{array}{l}\text { (sensitivity or specificity or diagnostic tests).mp. } \\
{[m p=t i, a b, h w, t c, i d, o t, t m, ~ s h, t n, d m, m f, d v, k w]}\end{array}$ & $1,162,714$ \\
\hline 8 & 2 or 7 & $1,164,908$ \\
\hline 9 & 6 and 8 & 4,565 \\
\hline 10 & Limit 9 to human & 4,180 \\
\hline 11 & Limit 10 to year = '1992-Current' & 3,778 \\
\hline 12 & $\begin{array}{l}\text { Limit } 11 \text { to '300 adulthood < age } 18 \text { years and older >' } \\
\text { [Limit not valid in Embase; records were retained] }\end{array}$ & 3,769 \\
\hline 13 & $\begin{array}{l}\text { Limit } 12 \text { to adulthood }<18+\text { years }>\text { [Limit not valid } \\
\text { in Embase; records were retained] }\end{array}$ & 3,769 \\
\hline
\end{tabular}

\section{Appendix 2: Set up of the hierarchical Bayesian models for the summary receiver operating characteristic (ROC) curves}

Model 1: proton pump inhibitor (PPI) studies

Assumption: imperfect reference standard

Prior distributions:

Prior of prevalence (pi) is beta $(12,12),<=>$ pi in $[0.3,0.7]$

Prior of beta is uniform $(-0.75,0.75)$

Prior of THETA is uniform $(-1.5,1.5)$

Prior of LAMBDA is uniform $(-3,3)$

Prior of sigma_alpha is uniform $(0,2)$

Prior of sigma_theta is uniform $(0,2)$

Prior of S2 (sensitivity of reference test) is:

Study(ies) 1 to 7 beta $(172.55,30.45),<=>$ S2 in $[0.8,0.9]$

Prior of $\mathrm{C} 2$ (specificity of reference test) is:

Study(ies) 1 to 7 beta $(50.4,12.6),<=>C 2$ in $[0.7,0.9]$

Model 2: exertional 24 h pH-metry

Assumption: imperfect reference standard

Prior distributions:

Prior of prevalence (pi) is beta $(5.2318,6.0194),<=>$ pi in $[0.18,0.75]$

Prior of beta is uniform $(-0.75,0.75)$

Prior of THETA is uniform $(-1.5,1.5)$

Prior of LAMBDA is uniform $(-3,3)$

Prior of sigma_alpha is uniform $(0,2)$

Prior of sigma_theta is uniform $(0,2)$ 
Prior of S2 (sensitivity of reference test) is: Study(ies) 1 to 5 beta $(172.55,30.45),<=>$ S2 in $[0.8,0.9]$

Prior of $\mathrm{C} 2$ (specificity of reference test) is:

Study(ies) 1 to 5 beta $(50.4,12.6),<=>C 2$ in $[0.7,0.9]$

\section{Appendix 3: Summary of excluded studies during full-text review}

In Table 5 summarizes the studies reviewed in full-text and excluded from the systematic review. For each study the reason for exclusion is provided.

Table 5 Summary of excluded studies during full-text review

\begin{tabular}{|c|c|c|c|}
\hline Author & Year & Design & Comments \\
\hline Aanen & 2008 & cohort, prospective & No diagnostic study. No NCCP. GERD, reproducibility of reflux symptoms only \\
\hline Abbass & 2009 & randomised clinical trial & No diagnostic study. No NCCP. General pain patients \\
\hline Achem & 1993 & retrospective, review & $\begin{array}{l}\text { Prevalence of nutcracker esophagus in NCCP. For treatment outcome open label trial with } \\
\text { small sample }\end{array}$ \\
\hline Achem & 1997 & randomised, controlled trial & No diagnostic study. GERD patients only received PPI \\
\hline Achem & 2000 & review article & Review article about atypical chest pain \\
\hline Adams & 2001 & retrospective review & no NCCP. Spiral CT in pulmonary embolism \\
\hline Adamek & 1995 & cross-sectional study & $\begin{array}{l}\text { No reference test. Description of coexistence of motility disorders and pathologic acid } \\
\text { reflux }\end{array}$ \\
\hline Aikens & 2001 & cross-sectional study & No diagnostic study, presence of fear in NCCP patients. Correlation of fear with symptoms \\
\hline Aizawa & 1993 & cross-sectional study & no NCCP, acetylcholine provocation test for coronary arterial spasm \\
\hline Ajanovic & 1999 & cross-sectional study & no NCCP. Pulmonary embolism \\
\hline Aksglaede & 2003 & experimental & Experimental. Small sample $(n=5)$ chest pain. \\
\hline Alexander & 1994 & cross-sectional study & Prevalence and nature of mental disorders in NCCP and IHD \\
\hline Amarasiri & 2010 & cross-sectional study & GERD patients not NCCP \\
\hline Anzai & 2000 & cross-sectional study & $\begin{array}{l}\text { No reference test, coronary flow reserve with dopler in patients with no significant } \\
\text { coronary stenosis }\end{array}$ \\
\hline Armstrong & 1992 & review article & Review article about atypical chest pain \\
\hline Arnold & 2009 & randomised clinical trial & No diagnostic study. Treatment outcome \\
\hline Aufderheide & 1996 & validation & Validation of ACI-TIPI probabilities for MI \\
\hline Bak & 1994 & cohort, prospective & No diagnostic study. Comparison of prevalence of findings \\
\hline Balaban & 1999 & experimental & No diagnostic study. Small sample $(n=10)$ \\
\hline Baniukiewicz & 1997 & cross-sectional study & No diagnostic study. Description of findings in upper Gl studies \\
\hline Barham & 1997 & observational & $\begin{array}{l}\text { No NCCP. Description of presence of esophageal spasm in patients undergoing } \\
\text { upper Gl studies }\end{array}$ \\
\hline Barki & 1996 & cohort, prospective & No diagnostic study. Description of clinical presentation in painful rip syndrome \\
\hline Basseri & 2011 & experimental & Experimental. No NCCP. Different techniques swallow studies \\
\hline Bassotti & 1998 & cohort, retrospective & No NCCP. Nutcracker esophagus and the symptoms and findings investigated. \\
\hline Bassotti & 1992 & cohort, prospective & No diagnostic study. Prevalence \\
\hline Beck & 1992 & cross-sectional study & $\begin{array}{l}\text { No diagnostic study. Charasteristics of NCCP patients compared to general } \\
\text { pain patients }\end{array}$ \\
\hline Belleville & 2010 & cross-sectional study & No diagnostic study. Characteristics of patients with panic disorders in the ER \\
\hline Berkovich & 2000 & cohort, retrospective & No NCCP \\
\hline Bernstein & 2002 & validation & GOLDmineR: improvement of a risk model \\
\hline Berthelot & 2005 & cohort, retrospective & No diagnostic study. Pain referral study after injection \\
\hline Bjorksten & 1999 & cross-sectional study & No patients, workers with muscoloskeletal complaints \\
\hline
\end{tabular}


Table 5 Summary of excluded studies during full-text review (Continued)

\begin{tabular}{|c|c|c|c|}
\hline Blatchford & 1999 & cross-sectional study & No NCCP. Emergency medical admission rates \\
\hline Borjesson & 1998 & cross-sectional study & Small sample $(n=18)$, prevalence of esophageal findings \\
\hline Borjesson & 1998 & $\begin{array}{l}\text { non-randomised controlled } \\
\text { trial }\end{array}$ & No diagnostic study. Small sample size ( $n=20$ per group). Intervention $=$ TENS \\
\hline Bortolotti & 2001 & experimental & No diagnostic study, small sample $(n=9)$ \\
\hline Bortolotti & 1997 & randomised clinical trial & No diagnostic study. L-Arginine in patients with NCCP. Small sample $(n=8)$ \\
\hline Bovero & 1993 & cohort, prospective & Duplicate of same study Bovero 1993 included in the analysis under different titel \\
\hline Bovero & 1993 & cohort, prospective & Duplicate of same study Bovero 1993 included in the analysis under different titel \\
\hline Brims & 2010 & review article & Review article about atypical chest pain \\
\hline Broekaert & 2006 & experimental & Experimental trial in volunteers (no patients, $\mathrm{n}=10$ ) \\
\hline Brunse & 2010 & cohort, prospective & No diagnostic study. Prevalence \\
\hline Brusori & 2001 & cross-sectional study & Mixed sample, diagnosis of esophageal dysmotility in fluoroscopy vs. Manometry \\
\hline Budzynski & 2010 & cross-sectional study & $\begin{array}{l}\text { Mixed patients sample with significant and non significant coronary leasons not } \\
\text { responding to PPI treatment }\end{array}$ \\
\hline Bruyninckx & 2009 & cross-sectional study & No diagnostic study. GP's reasons for referral \\
\hline Cameron & 2006 & case series & $\begin{array}{l}\text { Case series, selected sample by gastroenterologist. Not all patients had all } \\
\text { investigation. Small samples for each group }\end{array}$ \\
\hline Cannon & 1994 & randomised clinical trial & Treatment outcome (imipramine vs. placebo) \\
\hline Carter & 1997 & review article & Review article about atypical chest pain \\
\hline Cremonini & 2005 & review article & Systematic Review PPI \\
\hline Castell & 1998 & Editorial & Editorial \\
\hline Chambers & 1998 & observational & Small sample size: $n=23, S I$ in 7 patients not calculated \\
\hline Cheung & 2007 & cross-sectional study & $\begin{array}{l}\text { No diagnostic study. Questionnaire to doctors to see what kind of patients they } \\
\text { see, what diagnostic tests they use and how they treat. }\end{array}$ \\
\hline Christenson & 2004 & cohort, prospective & Chest discomfort inappropriately not diagnosed ACS. Different research question \\
\hline Crichton & 1997 & experimental & Experimental statistical rule out \\
\hline Cossentino & 2012 & randomised clinical trial & No diagnostic study. Baclofen in gastro-esophageal diseases \\
\hline Dekel & 2003 & cohort, retrospective & No diagnostic study. Prevalence of esophageal motility disorders. \\
\hline Dekel & 2004 & $\begin{array}{l}\text { Not randomised, not controlled } \\
\text { trial }\end{array}$ & PPI trial only 14 patients included (only GERD positive treated) \\
\hline Deng & 2009 & cross-sectional study & No NCCP. Combination between cardiac ischemia and esophageal spasms \\
\hline De Vries & 2006 & cross-sectional study & Mixed patient sample with cardiac and non-cardiac chest pain \\
\hline Dickman & 2007 & cohort, prospective & No diagnostic study. Prevalence of Gl findings in NCCP vs. patients with GERD \\
\hline Disla & 1994 & cohort, prospective & No diagnostic study, prevalence \\
\hline Domanovits & 2002 & cross-sectional study & Rule out cardiovascular disease. No diagnostic study for NCCP \\
\hline Ellis & 1992 & cohort, prospective & No diagnostic study. Treatment outcome in patients with esophageal spasm \\
\hline Elloway & 1992 & cross-sectional study & $\begin{array}{l}\text { provocative radionuclide esophagealNo comparison to reference test, } \\
\text { radionuclide esophageal transit (P-RET) investigation, small sample }(n=30)\end{array}$ \\
\hline Elloway & 1992 & cross-sectional study & Same study under different title \\
\hline Erhardt & 2002 & Guideline & Task force on the management of chest pain \\
\hline Esayag & 2008 & retrospective review & Pleuritic chest pain. No reference test, description of presentation and outcome \\
\hline Esler & 2001 & randomized clinical trial & Dissertation, same as following. \\
\hline Esler & 2003 & randomized clinical trial & Treatment intervention in NCCP. CBT in NCCP seems to reduce chest pain episodes \\
\hline Fass & 1999 & cohort, prospective & No diagnostic study. Treatment outcome study \\
\hline Fleischmann & 1997 & cross-sectional study & No NCCP. Echokardiographic findings in acute chest pain and health status \\
\hline Fletcher & 2011 & cohort, prospective & Sample size: 8 patients with NCCP \\
\hline Fornari & 2008 & cohort, retrospective & No NCCP. Only nutcracker esophagus investigated \\
\hline
\end{tabular}


Table 5 Summary of excluded studies during full-text review (Continued)

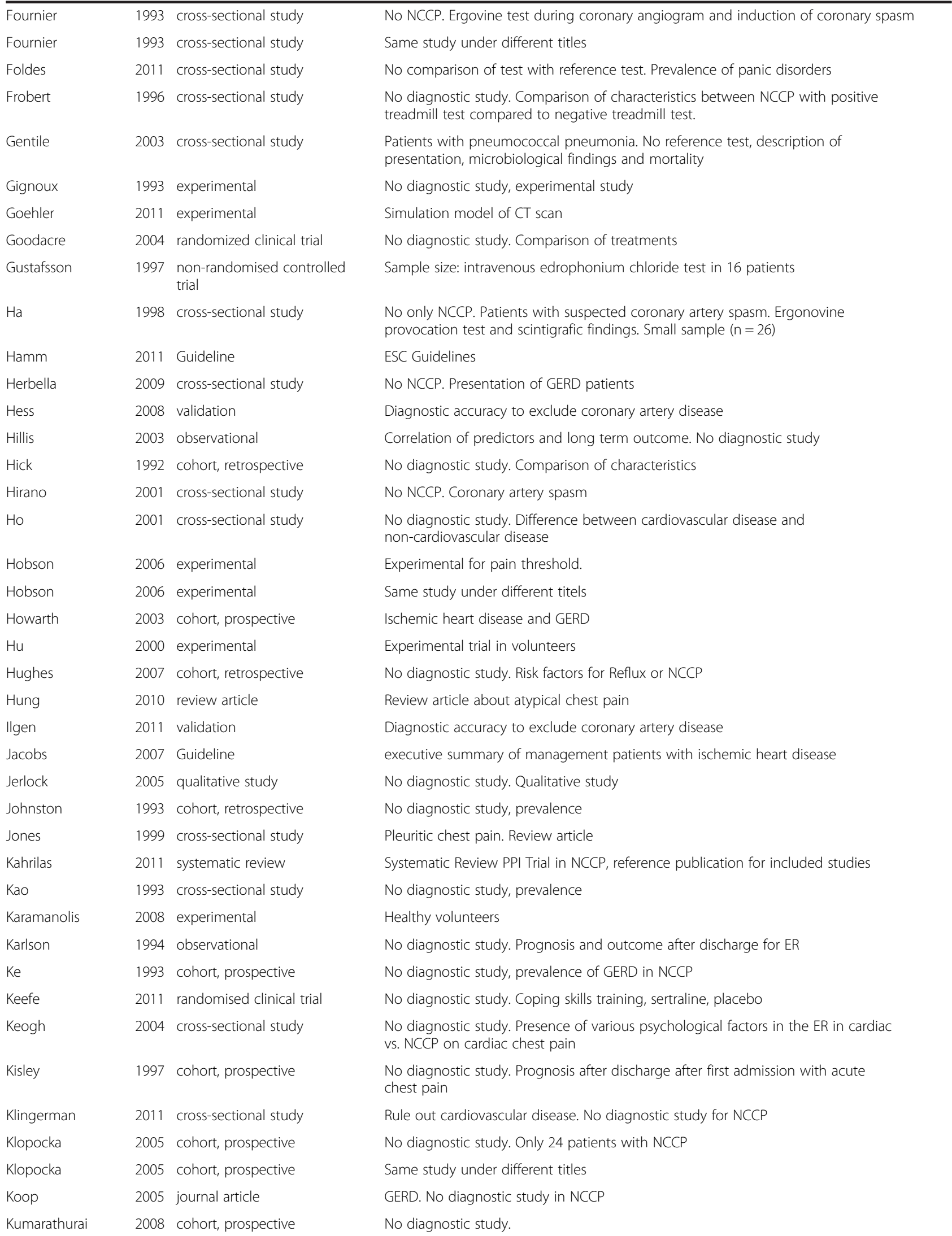


Table $\mathbf{5}$ Summary of excluded studies during full-text review (Continued)

\begin{tabular}{|c|c|c|c|}
\hline Kushner & 1992 & cross-sectional study & small sample: $n=27$. Presence of panic disorders in relatives. \\
\hline Lacy & 2009 & cross-sectional study & Prevalence study \\
\hline Lam & 1994 & cohort, prospective & $\begin{array}{l}\text { No diagnostic procedure. Only patients included that chest pain was reproduced } \\
\text { during the investigation }\end{array}$ \\
\hline Lanzarini & 1994 & cross-sectional study & $\begin{array}{l}\text { Description of findings in dobutamine stress echocardiography in patients with } \\
\text { positive exercise stress test and negative coronar angiography including } \\
\text { ergonovine stress test. }\end{array}$ \\
\hline Lauenbjerg & 1997 & observational & $\begin{array}{l}\text { No diagnostic study. Long term prognosis in patients with NCCP of various } \\
\text { etiologies }\end{array}$ \\
\hline Lee & 2011 & randomised clinical trial & Conference proceeding. No diagnostic study \\
\hline Lee & 2005 & cross-sectional study & Prevalence study \\
\hline Lehtola & 2010 & randomised, controlled trial & Treatment outcome (manipulation, acupuncture vs. placebo. No diagnostic study \\
\hline Lessard & 2012 & & $\begin{array}{l}\text { Patients with NCCP with Panic disorders. Two different interventions, no } \\
\text { diagnostic study }\end{array}$ \\
\hline Lien & 2011 & cohort, prospective & NCCP not investigated \\
\hline Lin & 2004 & cross-sectional study & $\begin{array}{l}\text { No NCCP. GERD symptoms and underlying conditions. Differences between women } \\
\text { and men }\end{array}$ \\
\hline Liu & 2006 & cross-sectional study & No NCCP patients. Correlation analysis between psychological factors and findings \\
\hline Lopez Gaston & 1994 & cross-sectional study & Only esophageal pain investigated not NCCP \\
\hline Lopez Gaston & 1994 & cross-sectional study & Same study under different titles \\
\hline Lopez Gaston & 1994 & cross-sectional study & Same study under different titles \\
\hline Loten & 2009 & observational & No diagnostic study. Adverse outcome / prognosis of mixed patient population \\
\hline Lyer & 2009 & retrospective review & Spontaneous pneumomediastinum. Presentation and findings. No diagnostic study \\
\hline MacPherson & 2007 & cross-sectional study & $\begin{array}{l}\text { No diagnostic study. Survey of patients after ER diagnosis NCCP about interest } \\
\text { in acupuncture }\end{array}$ \\
\hline Maev & 2007 & randomised clinical trial & Conference proceeding \\
\hline Maev & 2007 & randomised clinical trial & Same study under different titles \\
\hline Makk & 2000 & experimental & $\begin{array}{l}\text { Experimental study. No diagnostic study. Comparison of acid infusion and cardiac } \\
\text { vs. non-cardiac chest pain. Small sample }\end{array}$ \\
\hline Manchikanti & 2003 & observational & No NCCP. Medial branch blocks for musculoskeletal pain \\
\hline Manterola & 2004 & cross-sectional study & No diagnostic study. Clinical presentation of patients with NCCP \\
\hline Martina & 1997 & cross-sectional study & All patients presenting in primary care. NCCP not as subgroup investigated \\
\hline Matthews & 2005 & Meta-analysis & Meta-analysis for PPI-Trial \\
\hline Mayou & 1994 & cohort, prospective & No diagnostic study. Comparison of NCCP vs. IHD patients \\
\hline Mayou & 2002 & cohort, prospective & $\begin{array}{l}\text { No diagnostic study. One year follow-up in comparison to cardiac chest pain. } \\
\text { Comparison of costs to the CVD patients }\end{array}$ \\
\hline Mearin & 1998 & cohort study, prospective & No diagnostic study. Change of habits during manometry \\
\hline Mehta & 1995 & experimental & No reference test as "true positive" defined. \\
\hline Mendelson & 1997 & cohort, prospective & $\begin{array}{l}\text { Reference test are cancer patients. Comparison of Szintigraphy for the diagnosis } \\
\text { of costochondritis }\end{array}$ \\
\hline Mitchell & 2006 & cross-sectional study & Prevalence of risk factors and pretest probability \\
\hline Miniati & 1999 & cross-sectional study & no NCCP. Pulmonary embolism \\
\hline Miniati & 2001 & cross-sectional study & no NCCP. Pulmonary embolism \\
\hline Miniati & 2003 & cross-sectional study & no NCCP. Prediction model for pulmonary embolism \\
\hline Mujica & 2001 & cohort, prospective & No diagnostic study in patients. Healthy volunteers \\
\hline Mulero & 1999 & cross-sectional study & Small sample $(n=24)$. No reference test. Descriptive findings in SPECT \\
\hline Munk & 2008 & cohort, prospective & No diagnostic study. Risk of death in patients with unexplained chest pain \\
\hline Nanbu & 1997 & cross-sectional study & $\begin{array}{l}\text { Focus on difference between IHD and NCCP patients. Valdity of the medical } \\
\text { interview for patients with NCCP }\end{array}$ \\
\hline
\end{tabular}


Table 5 Summary of excluded studies during full-text review (Continued)

\begin{tabular}{|c|c|c|c|}
\hline Nasr & 2010 & experimental & Experimental study. \\
\hline Nasr & 2010 & experimental & Same study under different titels \\
\hline Nellemann & 2000 & experimental & Small sample ( $n=5$ with chest pain) \\
\hline Nevitt & 1999 & secondary analysis of an RCT & No NCCP. Vertebral fracture \\
\hline Nikolic & 2010 & cross-sectional study & No diagnostic study. Comparison of NCCP to IHD patients \\
\hline Nilsson & 2003 & cross-sectional study & Prevalence of Diagnosis of IHD in primary care. \\
\hline Okada & 1993 & cross-sectional study & No NCCP. Provocation of myocardial ischemia by hyperventilation \\
\hline Oliver & 1999 & cross-sectional study & $C T$ in acute non-cardiac chest pain. No reference. Description of diagnoses found. \\
\hline Pandak & 2002 & cross-sectional study & duplicate of the study included in the analysis \\
\hline Panju & 1996 & observational & No diagnostic study. Patients prognosis after discharge \\
\hline Paterson & 1993 & cohort, prospective & exclude, small sample \\
\hline Paterson & 1995 & cross-sectional study & $\begin{array}{l}\text { No diagnostic study. Description of finding in balloon distention NCCP in } \\
\text { comparison to other pain patients }\end{array}$ \\
\hline Paterson & 1996 & cross-sectional study & Not enough information to populate a two by two table. Small sample $(n=23)$ \\
\hline Porter-Moffitt & 2006 & cross-sectional study & Small sample (Chest pain $n=34$ ). Comparison of findings to other pain diagnosis. \\
\hline Rasmussen & 2009 & cohort, prospective & No NCCP. Complex regional pain syndrome \\
\hline Robertson & 2008 & cross-sectional study & Comparison of psychological morbidity in cardiac vs. Non-cardiac chest pain \\
\hline Rosano & 1996 & randomised clinical trial & $\begin{array}{l}\text { No diagnostic study. Treatment of 17-beta-estradiol patches compared to } \\
\text { placebo on NCCP in postmenopausal women }\end{array}$ \\
\hline Ratnaike & 1993 & retrospective review & No diagnostic study. Audit for IHD \\
\hline Rate & 1999 & experimental & healthy volunteers \\
\hline Rencoret & 2006 & cross-sectional study & $\begin{array}{l}\text { No diagnostic study. Prevalence of esophageal disorders in patients with NCCP } \\
\text { compared to other Gl diseases }\end{array}$ \\
\hline Repasky & 2005 & validation & ED chest pain pathway \\
\hline Rokkas & 1992 & cross-sectional study & Not enough information to populate the two by two table \\
\hline Rose & 1994 & cohort, prospective & $\begin{array}{l}\text { No diagnostic study. Does esophageal testing prevent persistence of symptoms? } \\
\text { No control group }\end{array}$ \\
\hline Rose & 1994 & cohort, prospective & Same study under different titles \\
\hline Rosengren & 2008 & Editorial & Editorial \\
\hline Rousset & 2011 & retrospective review & No NCCP. Catammenial pneumothorax and endometriosis-related pneumothorax \\
\hline Ruigomez & 2004 & cohort study & No diagnostic study. Description of risk factors, incidence and comorbidities \\
\hline Sakata & 1996 & cross-sectional study & $\begin{array}{l}\text { No reference test. Description of homeostasis and fibrinolysis in patients with } \\
\text { coronary artery spasm. Not sure only NCCP patients }\end{array}$ \\
\hline Sakamoto & 2011 & cross-sectional study & Acute chest pain, rule out aortic dissection or pulmonary embolism \\
\hline Salles & 2011 & cohort, retrospective & No diagnostic study: SAPHO syndrome, clinical characteristics. \\
\hline Sanchis & 2008 & cross-sectional study & $\begin{array}{l}\text { clinical risk profile of patients with acute chest pain without ST-segment deviation } \\
\text { or troponin elevation }\end{array}$ \\
\hline Scarinci & 1994 & cohort, prospective & No NCCP. Women with GERD clinical presentation \\
\hline Schima & 1992 & cohort, prospective & Small sample $(n=4$ NCCP) \\
\hline Schima & 1992 & cohort, prospective & Same study under different titles \\
\hline Schmidt & 2002 & cross-sectional study & No NCCP. General pain patients \\
\hline Schmulson & 2004 & review article & Review article about atypical chest pain \\
\hline Shahid & 2005 & cross-sectional study & No diagnostic study. Prensentation of young adults with chest pain \\
\hline Shapiro & 2006 & & $\begin{array}{l}\text { No NCCP patients. Functional heart burn (pH Man normal) vs. NERD } \\
\text { (ph manometry pathologic) incl. psychometric profile). }\end{array}$ \\
\hline Sharma & 2010 & experimental & healthy volunteers \\
\hline Shelby & 2009 & randomized clinical trial & Same sample as 210 and 217. Description of psychological factors at baseline. \\
\hline Sigurdsson & 2009 & retrospective review & Retrospective analysis of lung biopsy. No NCCP group \\
\hline
\end{tabular}


Table 5 Summary of excluded studies during full-text review (Continued)

\begin{tabular}{|c|c|c|c|}
\hline Singh & 1993 & retrospective review & duplicate of the included study \\
\hline Smith & 2000 & retrospective review & Feasibility study based on records in a chiropractic clinic. \\
\hline Smout & 1992 & experimental & experimental. Small sample $(n=10)$ \\
\hline Sobralske & 2005 & review article & Review article about atypical chest pain \\
\hline Spencer & 2006 & observational & No NCCP. Gl patients long term outcome \\
\hline Sporer & 2007 & cross-sectional study & Rule out cardiovascular disease. No diagnostic study for NCCP \\
\hline Stahl & 1994 & cohort, prospective & Small sample ( $\mathrm{n}=13$ NCCP patients) \\
\hline Steurer & 2010 & Metaanalysis & clinical value of diagnostic instruments to rule out IHD \\
\hline Stochkendahl & 2008 & randomised clinical trial & Study protocol \\
\hline Stochkendahl & 2012 & randomised, controlled trial & No diagnostic study. Treatment outcome \\
\hline Stochkendahl & 2012 & randomised, controlled trial & No diagnostic study. Same study as previous. Treatment outcome 1 year follow-up \\
\hline Stollman & 1997 & cross-sectional study & Small sample ( $\mathrm{n}=14$ patients) \\
\hline Taylor & 2002 & cross-sectional study & Rule out strategy cardiovascular patients. No diagnostic study in NCCP \\
\hline Taniguchi & 2009 & cross-sectional study & Chest pain in asthma. Treatment response to bronchodilatators \\
\hline Tew & 1995 & cross-sectional study & No diagnostic study. Outcome cardiovascular patients \\
\hline Tougas & 2001 & experimental & $\begin{array}{l}\text { Experimental. Autonomic reaction to acid infusion in NCCP patients }(n=28) \\
\text { compared to controls }\end{array}$ \\
\hline Triadafilopoulos & 1997 & cohort, prospective & GERD patients. Description of spectrum of patients. Only a few with NCCP \\
\hline Tutuian & 2006 & cross-sectional study & $\begin{array}{l}\text { Not enough information to populate a two by two table in NCCP patients with } \\
\text { esophageal spasm }\end{array}$ \\
\hline Valdovinos & 2004 & experimental & No reference test. pH Bravo- capsule. Safety, efficacy and experience in 11 patients \\
\hline Van Kleef & 1995 & observational & $\begin{array}{l}\text { No diagnostic study. Intervention success comparison after radiofrequency lesion } \\
\text { of the dorsal root ganglion }\end{array}$ \\
\hline $\begin{array}{l}\text { Van Peski- } \\
\text { Oosterbaan }\end{array}$ & 1998 & cross-sectional study & $\begin{array}{l}\text { Survey about how people are interested in psychological treatment after } \\
\text { discharge after cardiac unit admission. Mixed patients sample. }\end{array}$ \\
\hline van Ravensteijn & 2012 & systematic review & Diagnostic test efficacy in various pain patients \\
\hline Varia & 2000 & randomised, controlled trial & No diagnostic study. Comparison efficacy Sertraline vs. Placebo. \\
\hline Vent & 2010 & journal article & dysphagia cause of chest pain \\
\hline Verdon & 2010 & observational & Chest pain early diagnostic guess accuracy in GP's \\
\hline Vermeltfoort & 2009 & cross-sectional study & Mixed patient sample with cardiac and non-cardiac chest pain \\
\hline Volpicelli & 2008 & cohort, prospective & Pleural sonography for the diagnosis of pulmonary embolism \\
\hline Wang & 2011 & cross-sectional study & Conference proceeding \\
\hline Watkins & 2011 & journal article & Diagnosis and management of community-acquired pneumonia \\
\hline Weiner & 2006 & journal article & Cardiac markers in low-risk patients. No study \\
\hline Weingarten & 1993 & cross-sectional study & $\begin{array}{l}\text { No diagnostic study for NCCP. Reduction of length of stay by complying the } \\
\text { guidelines }\end{array}$ \\
\hline White & 2011 & cross-sectional study & no diagnostic study. Prevalence \\
\hline Wong & 2002 & cohort, prospective & no comparison to a reference test. Descriptive information only. \\
\hline Wulsin & 2002 & randomised clinical trial & no diagnostic study. Treatment of paroxetine vs. usual care \\
\hline Yelland & 2010 & review article & Review article about atypical chest pain \\
\hline Yu & 1997 & cross-sectional study & $\begin{array}{l}\text { Not enough information to populate a two by two table for symptom index } \\
\text { and the presence of GERD }\end{array}$ \\
\hline Zalar & 1995 & cross-sectional study & Conference proceeding \\
\hline Zarauza & 2003 & observational & No diagnostic study. Follow-up after discharge \\
\hline Zheng & 2008 & cross-sectional study & Small sample $(n=27)$ \\
\hline Zheng & 2008 & cross-sectional study & Same study under different title \\
\hline
\end{tabular}




\section{Appendix 4: Summary of the Scottish Intercollegiate Guidelines Network (SIGN) quality assessment [19]}

In Table 6 the study quality assessed by using the Scottish Intercollegiate Guidelines Network (SIGN) methodology checklist for diagnostic studies [19] is summarized. Study quality was assessed by two reviewers independently.

\section{Appendix 5: Summary of all tests evaluated}

Table 7 provides a detailed description of all tests and reference tests investigated. Sensitivity, specificity, positive predictive value (PPV), negative predictive value (NPV), prevalence, and post test prevalence are given.

Sensitivity calculated by TP/(TP + FN); specificity calculated by $\mathrm{TN} /(\mathrm{FP}+\mathrm{TN})$. Biomechanical dysfunction defined as chest pain presumably caused by mechanical

Table 6 Summary of the Scottish Intercollegiate Guidelines Network (SIGN) quality assessment [19]

\begin{tabular}{|c|c|c|c|c|c|c|c|c|c|c|c|c|c|c|}
\hline Lead author/study & 1.1 & 1.2 & 1.3 & 1.4 & 1.5 & 1.6 & 1.7 & 1.8 & 1.9 & 1.10 & 1.11 & 1.12 & 1.13 & 2.1 \\
\hline Dickman [31] & WC & WC & WC & WC & $W C$ & WC & WC & WC & WC & $W C$ & $W C$ & $W C$ & N/A & $\overline{++}$ \\
\hline Bautista [32] & WC & WC & WC & WC & WC & WC & WC & WC & WC & WC & WC & WC & N/A & ++ \\
\hline Fass [33] & WC & WC & WC & WC & WC & WC & WC & WC & WC & WC & WC & WC & WC & ++ \\
\hline Pandak [34] & WC & WC & WC & WC & WC & WC & WC & WC & WC & WC & WC & PA & PA & + \\
\hline Kim [35] & WC & WC & WC & WC & WC & WC & WC & WC & WC & WC & WC & PA & PA & ++ \\
\hline Xia [36] & WC & WC & WC & WC & WC & WC & WC & WC & WC & WC & WC & WC & WC & ++ \\
\hline Kushinir [37] & WC & WC & AA & PA & WC & WC & WC & WC & WC & NA & NA & N/A & PA & + \\
\hline Lacima [38] & WC & PA & WC & WC & WC & WC & WC & WC & WC & NA & NA & WC & WC & + \\
\hline Cooke [39] & WC & AA & WC & WC & WC & WC & WC & WC & WC & NA & NA & WC & WC & + \\
\hline Bovero [40] & WC & PA & WC & WC & WC & WC & WC & WC & WC & NA & NA & WC & WC & + \\
\hline Romand [41] & WC & AA & WC & WC & WC & WC & WC & WC & WC & NA & NA & WC & WC & + \\
\hline Abrahao [42] & WC & WC & WC & WC & WC & WC & WC & WC & WC & NA & NA & WC & WC & ++ \\
\hline Ho [29] & WC & PA & WC & WC & WC & WC & WC & WC & WC & NA & NA & PA & WC & + \\
\hline Kim [24] & WC & WC & WC & WC & WC & WC & WC & WC & WC & NA & NA & WC & WC & ++ \\
\hline Hong [25] & WC & WC & WC & WC & WC & WC & WC & WC & WC & NA & NA & WC & WC & ++ \\
\hline Netzer [26] & WC & $\mathrm{AA}$ & WC & WC & WC & WC & WC & PA & WC & NA & NA & $W C$ & WC & + \\
\hline Mousavi [27] & WC & WC & WC & WC & WC & WC & WC & WC & WC & NA & NA & WC & WC & ++ \\
\hline Singh [28] & WC & PA & WC & WC & WC & WC & WC & $\mathrm{AA}$ & WC & NA & NA & WC & WC & + \\
\hline Lam [30] & WC & PA & WC & WC & WC & WC & WC & WC & WC & NA & NA & WC & WC & + \\
\hline Achem [43] & WC & WC & WC & WC & WC & WC & WC & $\mathrm{AA}$ & WC & NA & NA & WC & WC & + \\
\hline Demiryoguran [48] & WC & WC & WC & WC & WC & WC & WC & WC & WC & WC & WC & WC & WC & ++ \\
\hline Foldes-Busque [49] & WC & WC & WC & WC & WC & WC & WC & WC & AA & WC & NA & WC & N/A & ++ \\
\hline Kujipers [47] & WC & WC & WC & WC & WC & WC & WC & WC & WC & NA & NA & WC & WC & ++ \\
\hline Katerndahl [51] & WC & $\mathrm{AA}$ & WC & WC & WC & WC & WC & WC & WC & WC & WC & WC & WC & ++ \\
\hline Fleet [50] & WC & WC & WC & WC & WC & WC & WC & WC & WC & WC & WC & WC & WC & ++ \\
\hline Stochkendahl [44] & WC & WC & WC & NA & WC & WC & PA & WC & WC & NA & NA & WC & WC & + \\
\hline Manchikanti [46] & WC & WC & WC & WC & PA & PA & WC & WC & WC & WC & PA & PA & WC & + \\
\hline Bosner [45] & WC & WC & WC & WC & WC & WC & WC & $\mathrm{AA}$ & WC & WC & $\mathrm{AA}$ & WC & WC & ++ \\
\hline
\end{tabular}

1.1: spectrum of patients is representative of patients who will receive the test; 1.2 : selection criteria described; 1.3 : reference standard is likely to classify the condition correctly; 1.4: period between reference standard and index test short enough; 1.5: whole sample received verification of diagnosis; 1.6 : patients receive same reference test regardless of index test results; 1.7: reference standard independent of index test; 1.8: execution of index test described in detail; 1.9: reference standard described in detail; 1.10: index test interpreted without knowledge of result of reference test; 1.11: reference standard results interpreted without knowledge of result index test; 1.12: uninterpretable or intermediate results are reported; 1.13 : explanation is provided for withdrawals; 2.1: reliability of the conclusion of the study. Risk of bias (2.1) is as follows. (++), high quality: most of the criteria have been fulfilled. If not fulfilled, the conclusions of the study are very unlikely to alter. (+), moderate quality: some criteria fulfilled. Criteria not adequately described are unlikely to alter the conclusions. (-), low quality: few or no criteria fulfilled. The conclusions are likely to alter.

$A A$ adequately addressed, N/A not applicable, NA not addressed, NR not reported, PA poorly addressed, WC well covered. 
Table 7 Summary of all tests evaluated

\begin{tabular}{|c|c|c|c|c|c|c|c|c|c|c|c|c|c|c|c|}
\hline Criteria & Evaluated test & Reference standard & TP & FP & FN & TN & Sensitivity & Specificity & PPV & NPV & $\mathrm{LR}+$ & LR- & Prevalence & $\begin{array}{l}\text { Post-test } \\
+ \\
\text { prevalence }\end{array}$ & $\begin{array}{l}\text { Post-test - } \\
\text { prevalence }\end{array}$ \\
\hline \multicolumn{16}{|l|}{ Symptoms } \\
\hline Kim et al. [24] & $\begin{array}{l}\text { NCCP with atypical GERD } \\
\text { symptoms }\end{array}$ & $\begin{array}{l}\text { Endoscopy (LA classification) } \\
\text { and/or } 24 \mathrm{~h} \mathrm{pH} \text {-metry (>4\%, } \\
\mathrm{pH}<4\end{array}$ & 3 & 20 & 5 & 6 & 0.38 & 0.23 & 0.13 & 0.55 & 0.49 & 2.71 & 24 & 13 & 45 \\
\hline Kim et al. [24] & NCCP with typical GERD symptoms & $\begin{array}{l}\text { Endoscopy (LA classification) } \\
\text { and/or } 24 \mathrm{~h} \mathrm{pH} \text {-metry (>4\%, } \\
\mathrm{pH}<4\end{array}$ & 11 & 2 & 5 & 6 & 0.69 & 0.75 & 0.85 & 0.55 & 2.75 & 0.42 & 67 & 85 & 45 \\
\hline $\begin{array}{l}\text { Mousavi et al. } \\
\text { [27] }\end{array}$ & NCCP with typical GERD symptoms & $\begin{array}{l}\text { GERD if two tests positive: } \\
\text { endoscopy (Hentzel-Dent), } \\
\text { Bernstein test, omeprazole } \\
\text { trial }\end{array}$ & 11 & 5 & 24 & 38 & 0.31 & 0.88 & 0.69 & 0.61 & 2.70 & 0.78 & 45 & 69 & 39 \\
\hline $\begin{array}{l}\text { Mousavi et al. } \\
\text { [27] }\end{array}$ & NCCP relieved by antacid & $\begin{array}{l}\text { GERD if two tests positive: } \\
\text { endoscopy (Hentzel-Dent), } \\
\text { Bernstein test, omeprazole } \\
\text { trial }\end{array}$ & 15 & 36 & 20 & 7 & 0.43 & 0.16 & 0.68 & 0.64 & 0.51 & 3.51 & 45 & 29 & 74 \\
\hline $\begin{array}{l}\text { Mousavi et al. } \\
\text { [27] }\end{array}$ & NCCP and heartburn in history & $\begin{array}{l}\text { GERD if two tests positive: } \\
\text { endoscopy (Hentzel-Dent), } \\
\text { Bernstein test, omeprazole } \\
\text { trial }\end{array}$ & 14 & 8 & 21 & 35 & 0.40 & 0.81 & 0.64 & 0.63 & 2.15 & 0.74 & 45 & 64 & 38 \\
\hline $\begin{array}{l}\text { Mousavi et al. } \\
\text { [27] }\end{array}$ & NCCP and regurgitation in history & $\begin{array}{l}\text { GERD if two tests positive: } \\
\text { endoscopy (Hentzel-Dent), } \\
\text { Bernstein test, omeprazole } \\
\text { trial }\end{array}$ & 17 & 7 & 18 & 36 & 0.49 & 0.84 & 0.71 & 0.67 & 2.98 & 0.61 & 45 & 71 & 33 \\
\hline $\begin{array}{l}\text { Hong et al. } \\
{[25]}\end{array}$ & NCCP & $\begin{array}{l}\text { Manometry (Specler } 2001 \\
\text { criteria) and/or } 24 \text { h pH-metry } \\
(>4 \% \mathrm{pH}<4)\end{array}$ & 72 & 114 & 128 & 148 & 0.36 & 0.56 & 0.39 & 0.54 & 0.83 & 1.13 & 43 & 39 & 46 \\
\hline $\begin{array}{l}\text { Hong et al. } \\
{[25]}\end{array}$ & Control: dysphagia & $\begin{array}{l}\text { Manometry (Specler } 2001 \\
\text { criteria) and/or } 24 \text { h pH-metry } \\
\text { (>4\% pH <4) }\end{array}$ & 27 & 26 & 181 & 228 & 0.13 & 0.90 & 0.51 & 0.56 & 1.27 & 0.97 & 45 & 51 & 44 \\
\hline $\begin{array}{l}\text { Hong et al. } \\
{[25]}\end{array}$ & Control: GERD-typical symptoms & $\begin{array}{l}\text { Manometry (Specler } 2001 \\
\text { criteria) and/or } 24 \text { h pH-metry } \\
\text { (>4\% pH <4) }\end{array}$ & 53 & 53 & 151 & 205 & 0.26 & 0.79 & 0.50 & 0.58 & 1.26 & 0.93 & 44 & 50 & 42 \\
\hline $\begin{array}{l}\text { Hong et al. } \\
{[25]}\end{array}$ & Dysphagia & Manometry & 16 & 37 & 84 & 325 & 0.16 & 0.90 & 0.30 & 0.80 & 1.57 & 0.94 & 22 & 30 & 21 \\
\hline $\begin{array}{l}\text { Hong et al. } \\
{[25]}\end{array}$ & Dysphagia & $24 \mathrm{~h} \mathrm{pH}$-metry & 4 & 49 & 63 & 346 & 0.06 & 0.88 & 0.08 & 0.85 & 0.48 & 1.07 & 15 & 8 & 15 \\
\hline $\begin{array}{l}\text { Hong et al. } \\
{[25]}\end{array}$ & Dysphagia & $\begin{array}{l}\text { Manometry and } 24 \mathrm{~h} \mathrm{pH}- \\
\text { metry }\end{array}$ & 7 & 46 & 23 & 386 & 0.23 & 0.89 & 0.13 & 0.94 & 2.19 & 0.86 & 7 & 13 & 6 \\
\hline $\begin{array}{l}\text { Hong et al. } \\
{[25]}\end{array}$ & NCCP & Manometry & 34 & 152 & 63 & 213 & 0.35 & 0.58 & 0.18 & 0.77 & 0.84 & 1.11 & 21 & 18 & 23 \\
\hline
\end{tabular}


Table 7 Summary of all tests evaluated (Continued)

\begin{tabular}{|c|c|c|c|c|c|c|c|c|c|c|c|c|c|c|c|}
\hline $\begin{array}{l}\text { Hong et al. } \\
{[25]}\end{array}$ & NCCP & $24 \mathrm{~h} \mathrm{pH}$-metry & 29 & 157 & 43 & 233 & 0.40 & 0.60 & 0.16 & 0.60 & 1.00 & 1.00 & 16 & 16 & 16 \\
\hline $\begin{array}{l}\text { Hong et al. } \\
{[25]}\end{array}$ & NCCP & $\begin{array}{l}\text { Manometry and } 24 \mathrm{~h} \mathrm{pH}- \\
\text { metry }\end{array}$ & 9 & 177 & 22 & 254 & 0.29 & 0.59 & 0.05 & 0.92 & 0.71 & 1.20 & 7 & 5 & 8 \\
\hline $\begin{array}{l}\text { Hong et al. } \\
{[25]}\end{array}$ & GERD-typical symptoms & Manometry & 19 & 87 & 81 & 275 & 0.19 & 0.76 & 0.18 & 0.77 & 0.79 & 1.07 & 22 & 18 & 23 \\
\hline $\begin{array}{l}\text { Hong et al. } \\
{[25]}\end{array}$ & GERD-typical symptoms & 24 h pH-metry & 23 & 83 & 49 & 307 & 0.32 & 0.79 & 0.22 & 0.86 & 1.50 & 0.86 & 16 & 22 & 14 \\
\hline $\begin{array}{l}\text { Hong et al. } \\
{[25]}\end{array}$ & GERD-typical symptoms & $\begin{array}{l}\text { Manometry and } 24 \mathrm{~h} \mathrm{pH}- \\
\text { metry }\end{array}$ & 11 & 95 & 20 & 336 & 0.35 & 0.78 & 0.10 & 0.94 & 1.61 & 0.83 & 7 & 10 & 6 \\
\hline $\begin{array}{l}\text { Netzer et al. } \\
{[26]}\end{array}$ & NCCP & $\begin{array}{l}\text { Manometry and/or } 24 \mathrm{~h} \mathrm{pH}- \\
\text { metry }(>10.5 \% \mathrm{pH}<4)\end{array}$ & 31 & 14 & 223 & 35 & 0.12 & 0.71 & 0.69 & 0.14 & 0.43 & 1.23 & 84 & 69 & 86 \\
\hline $\begin{array}{l}\text { Netzer et al. } \\
{[26]}\end{array}$ & Control: GERD-typical symptoms & $\begin{array}{l}\text { Manometry and/or } 24 \mathrm{~h} \mathrm{pH}- \\
\text { metry }(>10.5 \% \mathrm{pH}<4)\end{array}$ & 127 & 16 & 127 & 33 & 0.50 & 0.67 & 0.89 & 0.21 & 1.53 & 0.74 & 84 & 89 & 79 \\
\hline $\begin{array}{l}\text { Netzer et al. } \\
{[26]}\end{array}$ & Control: dysphagia & $\begin{array}{l}\text { Manometry and/or } 24 \mathrm{~h} \mathrm{pH}- \\
\text { metry }(>10.5 \% \mathrm{pH}<4)\end{array}$ & 48 & 8 & 206 & 41 & 0.19 & 0.84 & 0.86 & 0.17 & 1.16 & 0.97 & 84 & 86 & 83 \\
\hline $\begin{array}{l}\text { Netzer et al. } \\
{[26]}\end{array}$ & GERD-typical symptoms & $24 \mathrm{~h}$ pH-metry & 115 & 28 & 49 & 111 & 0.70 & 0.80 & 0.80 & 0.69 & 3.48 & 0.37 & 54 & 80 & 31 \\
\hline $\begin{array}{l}\text { Netzer et al. } \\
{[26]}\end{array}$ & Dysphagia & $24 \mathrm{~h}$ pH-metry & 6 & 50 & 158 & 89 & 0.04 & 0.64 & 0.11 & 0.36 & 0.10 & 1.50 & 54 & 11 & 64 \\
\hline $\begin{array}{l}\text { Netzer et al. } \\
{[26]}\end{array}$ & NCCP & $24 \mathrm{~h}$ pH-metry & 24 & 21 & 140 & 118 & 0.15 & 0.85 & 0.53 & 0.46 & 0.97 & 1.01 & 54 & 53 & 54 \\
\hline \multicolumn{16}{|l|}{ PPI trial } \\
\hline $\begin{array}{l}\text { Dickman et al. } \\
\text { [31] }\end{array}$ & $\begin{array}{l}\text { Rabeprazole } 20 \mathrm{mg} \text { twice a day for } \\
1 \text { week SIS } \geq 50 \%\end{array}$ & $\begin{array}{l}\text { Endoscopy (Hentzel-Dent } \\
\text { grades) and/or } 24 \mathrm{~h} \mathrm{pH} \text {-metry } \\
\text { (>4.2\% pH <4) }\end{array}$ & 12 & 2 & 4 & 17 & 0.75 & 0.89 & 0.86 & 0.81 & 7.13 & 0.28 & 46 & 86 & 19 \\
\hline $\begin{array}{l}\text { Dickman et al. } \\
\text { [31] }\end{array}$ & Placebo for 1 week & $\begin{array}{l}\text { Endoscopy (Hentzel-Dent } \\
\text { grades) and/or } 24 \mathrm{~h} \mathrm{pH} \text {-metry } \\
\text { (>4.2\% pH <4) }\end{array}$ & 3 & 4 & 13 & 15 & 0.19 & 0.79 & 0.43 & 0.54 & 0.89 & 1.03 & 46 & 43 & 46 \\
\hline $\begin{array}{l}\text { Bautista et al. } \\
\text { [32] }\end{array}$ & $\begin{array}{l}\text { Lansoprazole } 60 \mathrm{mg} \text { AM, } 30 \text { mg PM } \\
\text { for } 1 \text { week SIS } \geq 50 \%\end{array}$ & $\begin{array}{l}\text { Endoscopy (Hentzel-Dent } \\
\text { grades) and/or } 24 \mathrm{~h} \mathrm{pH} \text {-metry } \\
(>4.2 \% \mathrm{pH}<4)\end{array}$ & 14 & 2 & 4 & 20 & 0.78 & 0.91 & 0.875 & 0.833 & 8.56 & 0.24 & 45 & 88 & 17 \\
\hline $\begin{array}{l}\text { Bautista et al. } \\
\text { [32] }\end{array}$ & $\begin{array}{l}\text { Lansoprazole } 60 \mathrm{mg} \text { AM, } 30 \mathrm{mg} \text { PM } \\
\text { for } 1 \text { week SIS } \geq 65 \%\end{array}$ & $\begin{array}{l}\text { Endoscopy (Hentzel-Dent } \\
\text { grades) and/or } 24 \mathrm{~h} \mathrm{pH} \text {-metry } \\
(>4.2 \% \mathrm{pH}<4)\end{array}$ & 15 & 1 & 3 & 21 & 0.83 & 0.95 & 0.93 & 0.88 & 18.33 & 0.17 & 45 & 94 & 13 \\
\hline $\begin{array}{l}\text { Bautista et al. } \\
\text { [32] }\end{array}$ & Placebo for 1 week & $\begin{array}{l}\text { Endoscopy (Hentzel-Dent } \\
\text { grades) and/or } 24 \mathrm{~h} \mathrm{pH} \text {-metry } \\
\text { (>4.2\% pH <4) }\end{array}$ & 4 & 8 & 14 & 14 & 0.22 & 0.64 & 0.33 & 0.50 & 0.61 & 1.22 & 45 & 33 & 50 \\
\hline Fass et al. [33] & $\begin{array}{l}\text { Omeprazole } 40 \text { mg AM, } 20 \text { mg PM } \\
\text { for } 1 \text { week SIS } \geq 50 \%\end{array}$ & $\begin{array}{l}\text { Endoscopy (Hentzel-Dent } \\
\text { grades) and/or } 24 \text { h pH-metry } \\
\text { (>4.2\% pH <4) }\end{array}$ & 18 & 2 & 5 & 12 & 0.78 & 0.86 & 0.90 & 0.71 & 5.48 & 0.25 & 62 & 90 & 29 \\
\hline
\end{tabular}


Table 7 Summary of all tests evaluated (Continued)

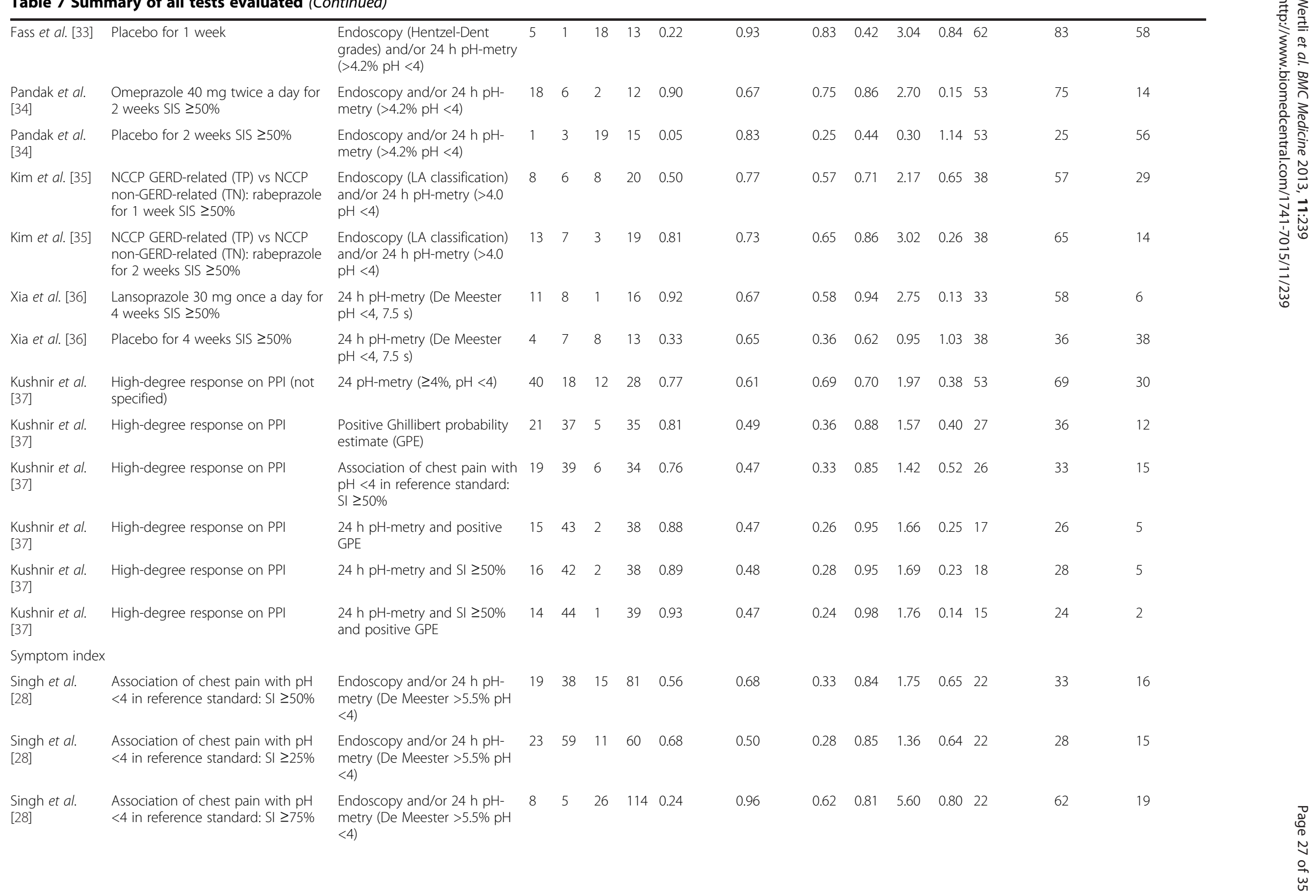


Table 7 Summary of all tests evaluated (Continued)

\begin{tabular}{|c|c|c|c|c|c|c|c|c|c|c|c|c|c|c|c|}
\hline $\begin{array}{l}\text { Singh et al. } \\
\text { [28] }\end{array}$ & $\begin{array}{l}\text { Association of heartburn with } \mathrm{pH} \\
<4 \text { in reference standard: Symptom } \\
\text { Index (SI) } \geq 50 \%\end{array}$ & $\begin{array}{l}\text { Endoscopy and/or } 24 \mathrm{~h} \mathrm{pH}- \\
\text { metry (De Meester }>5.5 \% \mathrm{pH} \\
<4 \text { ) }\end{array}$ & 40 & 32 & 3 & 78 & 0.93 & 0.71 & 0.56 & 0.96 & 3.20 & 0.10 & 28 & 56 & 4 \\
\hline $\begin{array}{l}\text { Singh et al. } \\
{[28]}\end{array}$ & $\begin{array}{l}\text { Association of heartburn with } \mathrm{pH} \\
<4 \text { in reference standard: } \mathrm{SI} \geq 25 \%\end{array}$ & $\begin{array}{l}\text { Endoscopy and/or } 24 \mathrm{~h} \mathrm{pH}- \\
\text { metry (De Meester }>5.5 \% \mathrm{pH} \\
<4 \text { ) }\end{array}$ & 41 & 40 & 2 & 70 & 0.95 & 0.64 & 0.51 & 0.97 & 2.62 & 0.07 & 28 & 51 & 3 \\
\hline $\begin{array}{l}\text { Singh et al. } \\
{[28]}\end{array}$ & $\begin{array}{l}\text { Association of heartburn with } \mathrm{pH} \\
<4 \text { in reference standard: } \mathrm{SI} \geq 75 \%\end{array}$ & $\begin{array}{l}\text { Endoscopy and/or } 24 \mathrm{~h} \mathrm{pH}- \\
\text { metry (De Meester }>5.5 \% \mathrm{pH} \\
<4 \text { ) }\end{array}$ & 25 & 25 & 9 & 94 & 0.74 & 0.79 & 0.50 & 0.91 & 3.50 & 0.34 & 28 & 58 & 12 \\
\hline Ho et al. [29] & $\begin{array}{l}\text { Association of chest pain with } \mathrm{pH} \\
<4 \text { in reference standard: } \mathrm{SI}>50 \%\end{array}$ & $\begin{array}{l}24 \mathrm{~h} \mathrm{pH} \text {-metry }(>4 \% \mathrm{pH}<4, \\
4 \mathrm{~s})\end{array}$ & 3 & 9 & 11 & 38 & 0.21 & 0.81 & 0.25 & 0.78 & 1.12 & 0.97 & 23 & 25 & 22 \\
\hline Lam et al. [30] & $\begin{array}{l}\text { Association of chest pain with } \mathrm{pH} \\
<4 \text { in reference standard: } \mathrm{Sl} \geq 75 \%\end{array}$ & $\begin{array}{l}24 \mathrm{~h} \mathrm{pH} \text {-metry (execution in } \\
\text { acute stage) }\end{array}$ & 13 & 0 & 15 & 13 & 0.46 & 1.00 & 1.00 & 0.48 & 13.03 & 0.54 & 68 & 97 & 54 \\
\hline \multicolumn{16}{|l|}{ Others } \\
\hline $\begin{array}{l}\text { Lacima et al. } \\
\text { [38] }\end{array}$ & 24 h-manometry $(\mathrm{pH}<4)$ & $\begin{array}{l}\text { Manometry during hospital } \\
\text { stay }\end{array}$ & 18 & 24 & 18 & 30 & 0.50 & 0.56 & 0.43 & 0.56 & 1.13 & 0.90 & 40 & 43 & 38 \\
\hline \multicolumn{16}{|c|}{ Provocation test } \\
\hline $\begin{array}{l}\text { Cooke et al. } \\
\text { [39] }\end{array}$ & NCCP during exertional pH-metry & $\begin{array}{l}24 \mathrm{~h} \mathrm{pH} \text {-metry }(5.5 \% \mathrm{pH}<4 \\
\text { for } 10 \mathrm{~s})\end{array}$ & 4 & 0 & 15 & 31 & 0.21 & 1.00 & 1.00 & 0.67 & 14.40 & 0.79 & 38 & 90 & 33 \\
\hline $\begin{array}{l}\text { Cooke et al. } \\
\text { [39] }\end{array}$ & $\begin{array}{l}\text { Control group: CVD with angina: } \\
\text { exertional pH-metry }\end{array}$ & $\begin{array}{l}24 \mathrm{~h} \mathrm{pH} \text {-metry }(5.5 \% \mathrm{pH}<4 \\
\text { for } 10 \mathrm{~s})\end{array}$ & 1 & 1 & 2 & 12 & 0.33 & 0.92 & 0.50 & 0.86 & 4.33 & 0.72 & 19 & 50 & 14 \\
\hline $\begin{array}{l}\text { Bovero et al. } \\
{[40]}\end{array}$ & $\begin{array}{l}\text { NCCP with normal ECG during } \\
\text { exertional pH-metry }\end{array}$ & $\begin{array}{l}24 \mathrm{~h} \text { pH-metry (De Meester } \\
\text { criteria: }>4.5 \% \mathrm{pH}<4) \text { ) }\end{array}$ & 17 & 1 & 29 & 20 & 0.37 & 0.95 & 0.94 & 0.41 & 7.76 & 0.66 & 69 & 94 & 59 \\
\hline $\begin{array}{l}\text { Bovero et al. } \\
{[40]}\end{array}$ & $\begin{array}{l}\text { NCCP at rest: NCCP with normal } \\
\text { ECG during exertional pH-metry }\end{array}$ & $\begin{array}{l}24 \mathrm{~h} \text { pH-metry (De Meester } \\
\text { criteria: }>4.5 \% \mathrm{pH}<4))\end{array}$ & 11 & 1 & 23 & 11 & 0.32 & 0.92 & 0.92 & 0.32 & 3.88 & 0.74 & 74 & 92 & 68 \\
\hline $\begin{array}{l}\text { Bovero et al. } \\
{[40]}\end{array}$ & $\begin{array}{l}\text { NCCP exertion/mixed: NCCP with } \\
\text { normal ECG during exertional pH- } \\
\text { metry }\end{array}$ & $\begin{array}{l}24 \mathrm{~h} \text { pH-metry (De Meester } \\
\text { criteria: }>4.5 \% \mathrm{pH}<4) \text { ) }\end{array}$ & 6 & 0 & 6 & 9 & 0.50 & 1.00 & 1.00 & 0.60 & 10.00 & 0.50 & 57 & 93 & 40 \\
\hline $\begin{array}{l}\text { Bovero et al. } \\
\text { [40] }\end{array}$ & $\begin{array}{l}24 \mathrm{~h} \mathrm{pH} \text {-metry (De Meester criteria: } \\
>4.5 \% \mathrm{pH}<4) \text { ) }\end{array}$ & $\begin{array}{l}\text { NCCP with normal ECG } \\
\text { during exertional pH-metry }\end{array}$ & 17 & 29 & 1 & 20 & 0.94 & 0.41 & 0.37 & 0.95 & 1.60 & 0.14 & 27 & 37 & 5 \\
\hline $\begin{array}{l}\text { Bovero et al. } \\
\text { [40] }\end{array}$ & $\begin{array}{l}24 \mathrm{~h} \mathrm{pH} \text {-metry (De Meester criteria: } \\
>4.5 \% \mathrm{pH}<4) \text { ) }\end{array}$ & $\begin{array}{l}\text { NCCP at rest: NCCP with } \\
\text { normal ECG during exertional } \\
\text { pH-metry }\end{array}$ & 11 & 23 & 1 & 11 & 0.92 & 0.32 & 0.32 & 0.92 & 1.36 & 0.26 & 26 & 32 & 8 \\
\hline $\begin{array}{l}\text { Romand et al. } \\
\text { [41] }\end{array}$ & $\begin{array}{l}\text { NCCP: } \mathrm{pH}<4 \text { for } 10 \text { s during } \\
\text { exertional pH-metry }\end{array}$ & $\begin{array}{l}24 \mathrm{~h} \text { pH-metry (De Meester } \\
\text { criteria: }>4.5 \% \mathrm{pH}<4) \text { ) }\end{array}$ & 7 & 14 & 3 & 19 & 0.70 & 0.58 & 0.33 & 0.86 & 1.65 & 0.52 & 23 & 33 & 14 \\
\hline $\begin{array}{l}\text { Abrahao et al. } \\
\text { [42] }\end{array}$ & $\begin{array}{l}\text { NCCP reproducible during balloon } \\
\text { distension }\end{array}$ & $\begin{array}{l}\text { Endoscopy (Savary-Miller) } \\
\text { and/or manometry and/or } \\
\text { pH-metry (De Meester criteria: } \\
>4.5 \% \mathrm{pH}<4\end{array}$ & 14 & 1 & 21 & 4 & 0.40 & 0.80 & 0.93 & 0.16 & 2.00 & 0.75 & 88 & 93 & 84 \\
\hline
\end{tabular}


Table 7 Summary of all tests evaluated (Continued)

\begin{tabular}{|c|c|c|c|c|c|c|c|c|c|c|c|c|c|c|c|}
\hline $\begin{array}{l}\text { Abrahao et al. } \\
\text { [42] }\end{array}$ & $\begin{array}{l}\text { NCCP reproducible during Tensilon } \\
\text { test }\end{array}$ & $\begin{array}{l}\text { Endoscopy (Savary-Miller) } \\
\text { and/or manometry and/or } \\
\mathrm{pH} \text {-metry (De Meester criteria: } \\
>4.5 \% \mathrm{pH}<4\end{array}$ & 6 & 2 & 29 & 3 & 0.17 & 0.60 & 0.75 & 0.09 & 0.43 & 1.38 & 88 & 75 & 91 \\
\hline $\begin{array}{l}\text { Abrahao et al. } \\
\text { [42] }\end{array}$ & $\begin{array}{l}\text { NCCP reproducible during } \\
\text { Bernstein test }\end{array}$ & $\begin{array}{l}\text { Endoscopy (Savary-Miller) } \\
\text { and/or manometry and/or } \\
\text { pH-metry (De Meester criteria: } \\
>4.5 \% \mathrm{pH}<4\end{array}$ & 9 & 1 & 26 & 4 & 0.26 & 0.80 & 0.90 & 0.13 & 1.29 & 0.93 & 88 & 90 & 87 \\
\hline $\begin{array}{l}\text { Abrahao et al. } \\
\text { [42] }\end{array}$ & $\begin{array}{l}\text { Tensilon and Bernstein Test and } \\
\text { balloon distension }(+ \text { if } 1 \text { test }+)\end{array}$ & $\begin{array}{l}\text { Endoscopy (Savary-Miller) } \\
\text { and/or manometry and/or } \\
\text { pH-metry (De Meester criteria: } \\
>4.5 \% \mathrm{pH}<4\end{array}$ & 20 & 3 & 15 & 2 & 0.57 & 0.40 & 0.87 & 0.12 & 0.95 & 1.07 & 88 & 87 & 88 \\
\hline $\begin{array}{l}\text { Abrahao et al. } \\
\text { [42] }\end{array}$ & $\begin{array}{l}\text { NCCP reproducible during Tensilon } \\
\text { test }\end{array}$ & $\begin{array}{l}\text { Endoscopy (Savary-Miller) } \\
\text { and/or } \mathrm{pH} \text {-metry (De Meester } \\
\text { criteria: }>4.5 \% \mathrm{pH}<4\end{array}$ & 6 & 2 & 26 & 6 & 0.19 & 0.75 & 0.75 & 0.19 & 0.75 & 1.08 & 80 & 75 & 81 \\
\hline $\begin{array}{l}\text { Abrahao et al. } \\
\text { [42] }\end{array}$ & $\begin{array}{l}\text { NCCP reproducible during } \\
\text { Bernstein test }\end{array}$ & $\begin{array}{l}\text { Endoscopy (Savary-Miller) } \\
\text { and/or } \mathrm{pH} \text {-metry (De Meester } \\
\text { criteria: }>4.5 \% \mathrm{pH}<4\end{array}$ & 8 & 2 & 24 & 6 & 0.25 & 0.75 & 0.80 & 0.20 & 1.00 & 1.00 & 80 & 80 & 80 \\
\hline $\begin{array}{l}\text { Abrahao et al. } \\
\text { [42] }\end{array}$ & $\begin{array}{l}\text { NCCP reproducible during balloon } \\
\text { distension }\end{array}$ & $\begin{array}{l}\text { Endoscopy (Savary-Miller) } \\
\text { and/or } \mathrm{pH} \text {-metry (De Meester } \\
\text { criteria: }>4.5 \% \mathrm{pH}<4\end{array}$ & 13 & 2 & 19 & 6 & 0.41 & 0.75 & 0.87 & 0.24 & 1.63 & 0.79 & 80 & 87 & 76 \\
\hline $\begin{array}{l}\text { Abrahao et al. } \\
\text { [42] }\end{array}$ & $\begin{array}{l}\text { Tensilon and Bernstein Test and } \\
\text { balloon distension }(+ \text { if } 1 \text { test }+)\end{array}$ & $\begin{array}{l}\text { Endoscopy (Savary-Miller) } \\
\text { and/or } \mathrm{pH} \text {-metry (De Meester } \\
\text { criteria: }>4.5 \% \mathrm{pH}<4\end{array}$ & 18 & 5 & 14 & 3 & 0.56 & 0.38 & 0.78 & 0.18 & 0.90 & 1.17 & 80 & 78 & 82 \\
\hline Ho et al. [29] & $\begin{array}{l}\text { NCCP reproducible during } \\
\text { Bernstein test }\end{array}$ & Endoscopy & 4 & 7 & 3 & 56 & 0.57 & 0.89 & 0.36 & 0.95 & 5.14 & 0.48 & 10 & 36 & 5 \\
\hline \multicolumn{16}{|l|}{ Eosinophilia } \\
\hline $\begin{array}{l}\text { Achem et al. } \\
\text { [43] }\end{array}$ & Current GERD symptoms & Esophageal biopsies & 10 & 26 & 14 & 121 & 0.42 & 0.82 & 0.28 & 0.90 & 2.36 & 0.71 & 14 & 28 & 10 \\
\hline $\begin{array}{l}\text { Achem et al. } \\
\text { [43] }\end{array}$ & $\begin{array}{l}\text { Male gender or current GERD } \\
\text { symptoms }\end{array}$ & Esophageal biopsies & 18 & 69 & 6 & 78 & 0.75 & 0.53 & 0.21 & 0.93 & 1.60 & 0.47 & 14 & 21 & 7 \\
\hline $\begin{array}{l}\text { Achem et al. } \\
\text { [43] }\end{array}$ & $\begin{array}{l}\text { Male gender or any abnormal EoE } \\
\text { endoscopic finding }\end{array}$ & Esophageal biopsies & 23 & 79 & 1 & 68 & 0.96 & 0.46 & 0.23 & 0.99 & 1.78 & 0.09 & 14 & 23 & 1 \\
\hline $\begin{array}{l}\text { Achem et al. } \\
\text { [43] }\end{array}$ & $\begin{array}{l}\text { Current GERD symptoms or any } \\
\text { abnormal EoE endoscopic finding }\end{array}$ & Esophageal biopsies & 20 & 63 & 4 & 84 & 0.83 & 0.57 & 0.24 & 0.96 & 1.94 & 0.29 & 14 & 24 & 5 \\
\hline \multicolumn{16}{|l|}{ Musculoskeletal } \\
\hline $\begin{array}{l}\text { Stochkendahl } \\
\text { et al. [44] }\end{array}$ & Biomechanical dysfunction & $\begin{array}{l}\text { Standardized examination } \\
\text { protocol }\end{array}$ & 112 & 120 & 0 & 70 & 1.00 & 0.37 & 0.48 & 1.00 & 1.58 & 0.00 & 37 & 48 & 0 \\
\hline $\begin{array}{l}\text { Stochkendahl } \\
\text { et al. [44] }\end{array}$ & $\geq 3$ of 5 overall palpation findings & $\begin{array}{l}\text { Standardized examination } \\
\text { protocol }\end{array}$ & 111 & 124 & 1 & 66 & 0.99 & 0.35 & 0.47 & 0.99 & 1.52 & 0.03 & 37 & 47 & 1 \\
\hline
\end{tabular}


Table 7 Summary of all tests evaluated (Continued)

\begin{tabular}{|c|c|c|c|c|c|c|c|c|c|c|c|c|c|c|c|}
\hline $\begin{array}{l}\text { Bosner et al. } \\
{[45]}\end{array}$ & $\begin{array}{l}\text { Chest wall symptom (CWS) score: } \\
\text { localized muscle tension, stinging } \\
\text { pain, pain reproducible by } \\
\text { palpation, absence of cough, cut- } \\
\text { off test negative } 0 \text { to } 1 \text { points }\end{array}$ & $\begin{array}{l}\text { Interdisciplinary consensus: } \\
\text { cardiologist, GP, research } \\
\text { associate (based on reviewed } \\
\text { baseline, follow-up data) }\end{array}$ & 506 & 318 & 59 & 329 & 0.90 & 0.51 & 0.66 & 0.82 & 1.82 & 0.20 & 47 & 61 & 15 \\
\hline $\begin{array}{l}\text { Bosner et al. } \\
{[45]}\end{array}$ & $\begin{array}{l}\text { CWS score: localized muscle } \\
\text { tension, stinging pain, pain } \\
\text { reproducible by palpation, absence } \\
\text { of cough, cut-off test negative } 0 \text { to } \\
2 \text { points }\end{array}$ & Interdisciplinary consensus & 357 & 135 & 208 & 512 & 0.63 & 0.79 & 0.76 & 0.67 & 3.02 & 0.47 & 47 & 72 & 29 \\
\hline $\begin{array}{l}\text { Stochkendahl } \\
\text { et al. [44] }\end{array}$ & Anterior chest wall tenderness & $\begin{array}{l}\text { Standardized examination } \\
\text { protocol }\end{array}$ & 110 & 134 & 2 & 56 & 0.98 & 0.29 & 0.45 & 0.97 & 1.39 & 0.06 & 37 & 45 & 3 \\
\hline $\begin{array}{l}\text { Stochkendahl } \\
\text { et al. [44] }\end{array}$ & $\begin{array}{l}\text { Angina pectoris (uncertain or } \\
\text { negative) }\end{array}$ & $\begin{array}{l}\text { Standardized examination } \\
\text { protocol }\end{array}$ & 109 & 147 & 3 & 43 & 0.97 & 0.23 & 0.43 & 0.94 & 1.26 & 0.12 & 37 & 43 & 7 \\
\hline $\begin{array}{l}\text { Stochkendahl } \\
\text { et al. [44] }\end{array}$ & Pain worse on movement of torso & $\begin{array}{l}\text { Standardized examination } \\
\text { protocol }\end{array}$ & 32 & 16 & 80 & 174 & 0.29 & 0.92 & 0.67 & 0.69 & 3.39 & 0.78 & 37 & 67 & 32 \\
\hline $\begin{array}{l}\text { Bosner et al. } \\
{[45]}\end{array}$ & Pain worse with movement & Interdisciplinary consensus & 221 & 119 & 344 & 528 & 0.39 & 0.82 & 0.65 & 0.61 & 2.13 & 0.75 & 47 & 65 & 40 \\
\hline $\begin{array}{l}\text { Stochkendahl } \\
\text { et al. [44] }\end{array}$ & $\begin{array}{l}\text { Positive/possible belief in pain } \\
\text { origin from muscle/joints }\end{array}$ & $\begin{array}{l}\text { Standardized examination } \\
\text { protocol }\end{array}$ & 108 & 156 & 4 & 34 & 0.96 & 0.18 & 0.41 & 0.90 & 1.17 & 0.20 & 37 & 41 & 11 \\
\hline $\begin{array}{l}\text { Stochkendahl } \\
\text { et al. [44] }\end{array}$ & Pain relief on pain medication & $\begin{array}{l}\text { Standardized examination } \\
\text { protocol }\end{array}$ & 25 & 13 & 87 & 177 & 0.22 & 0.93 & 0.66 & 0.67 & 3.26 & 0.83 & 37 & 66 & 33 \\
\hline $\begin{array}{l}\text { Bosner et al. } \\
{[45]}\end{array}$ & Pain reproducible by palpation & Interdisciplinary consensus & 351 & 193 & 214 & 454 & 0.62 & 0.70 & 0.68 & 0.64 & 2.08 & 0.54 & 47 & 65 & 32 \\
\hline $\begin{array}{l}\text { Stochkendahl } \\
\text { et al. [44] }\end{array}$ & Paraspinal tenderness & $\begin{array}{l}\text { Standardized examination } \\
\text { protocol }\end{array}$ & 90 & 112 & 22 & 78 & 0.80 & 0.41 & 0.45 & 0.78 & 1.36 & 0.48 & 37 & 45 & 22 \\
\hline $\begin{array}{l}\text { Bosner et al. } \\
{[45]}\end{array}$ & Localized muscle tension & Interdisciplinary consensus & 346 & 164 & 219 & 483 & 0.61 & 0.75 & 0.71 & 0.66 & 2.41 & 0.52 & 47 & 68 & 32 \\
\hline $\begin{array}{l}\text { Stochkendahl } \\
\text { et al. [44] }\end{array}$ & Chest pain present now & $\begin{array}{l}\text { Standardized examination } \\
\text { protocol }\end{array}$ & 92 & 116 & 20 & 74 & 0.82 & 0.39 & 0.44 & 0.79 & 1.35 & 0.46 & 37 & 44 & 21 \\
\hline $\begin{array}{l}\text { Bosner et al. } \\
{[45]}\end{array}$ & Pain now & Interdisciplinary consensus & 328 & 327 & 237 & 320 & 0.58 & 0.49 & 0.50 & 0.57 & 1.15 & 0.85 & 47 & 50 & 43 \\
\hline $\begin{array}{l}\text { Stochkendahl } \\
\text { et al. [44] }\end{array}$ & Pain debut not during a meal & $\begin{array}{l}\text { Standardized examination } \\
\text { protocol }\end{array}$ & 109 & 168 & 3 & 22 & 0.97 & 0.12 & 0.39 & 0.88 & 1.10 & 0.23 & 37 & 39 & 12 \\
\hline $\begin{array}{l}\text { Stochkendahl } \\
\text { et al. [44] }\end{array}$ & Sharp pain & $\begin{array}{l}\text { Standardized examination } \\
\text { protocol }\end{array}$ & 39 & 35 & 73 & 155 & 0.35 & 0.82 & 0.53 & 0.68 & 1.89 & 0.80 & 37 & 53 & 32 \\
\hline $\begin{array}{l}\text { Bosner et al. } \\
{[45]}\end{array}$ & Stinging pain & Interdisciplinary consensus & 299 & 184 & 266 & 463 & 0.53 & 0.72 & 0.62 & 0.63 & 1.87 & 0.66 & 47 & 62 & 37 \\
\hline $\begin{array}{l}\text { Stochkendahl } \\
\text { et al. [44] }\end{array}$ & $\begin{array}{l}\text { Hard physical exercise at least once } \\
\text { a week }\end{array}$ & $\begin{array}{l}\text { Standardized examination } \\
\text { protocol }\end{array}$ & 42 & 60 & 70 & 130 & 0.38 & 0.68 & 0.41 & 0.65 & 1.19 & 0.91 & 37 & 41 & 35 \\
\hline $\begin{array}{l}\text { Stochkendahl } \\
\text { et al. [44] }\end{array}$ & Pain not provoked during a meal & $\begin{array}{l}\text { Standardized examination } \\
\text { protocol }\end{array}$ & 109 & 170 & 3 & 20 & 0.97 & 0.11 & 0.39 & 0.87 & 1.09 & 0.25 & 37 & 39 & 13 \\
\hline
\end{tabular}


Table 7 Summary of all tests evaluated (Continued)

\begin{tabular}{|c|c|c|c|c|c|c|c|c|c|c|c|c|c|c|c|}
\hline $\begin{array}{l}\text { Stochkendahl } \\
\text { et al. [44] }\end{array}$ & Not sudden debut & $\begin{array}{l}\text { Standardized examination } \\
\text { protocol }\end{array}$ & 53 & 31 & 59 & 159 & 0.47 & 0.84 & 0.63 & 0.73 & 2.90 & 0.63 & 37 & 63 & 27 \\
\hline $\begin{array}{l}\text { Bosner et al. } \\
{[45]}\end{array}$ & Pain $>24 \mathrm{~h}$ & Interdisciplinary consensus & 158 & 139 & 407 & 508 & 0.28 & 0.79 & 0.53 & 0.56 & 1.30 & 0.92 & 47 & 54 & 45 \\
\hline $\begin{array}{l}\text { Stochkendahl } \\
\text { et al. [44] }\end{array}$ & Age $\leq 49$ years old & $\begin{array}{l}\text { Standardized examination } \\
\text { protocol }\end{array}$ & 67 & 54 & 45 & 136 & 0.60 & 0.72 & 0.55 & 0.75 & 2.10 & 0.56 & 37 & 55 & 25 \\
\hline $\begin{array}{l}\text { Bosner et al. } \\
{[45]}\end{array}$ & Pain mostly at noon time & Interdisciplinary consensus & 13 & 30 & 552 & 617 & 0.02 & 0.95 & 0.31 & 0.53 & 0.50 & 1.02 & 47 & 31 & 48 \\
\hline $\begin{array}{l}\text { Bosner et al. } \\
\text { [45] }\end{array}$ & Cough & Interdisciplinary consensus & 31 & 129 & 534 & 518 & 0.06 & 0.80 & 0.19 & 0.49 & 0.28 & 1.18 & 47 & 20 & 51 \\
\hline $\begin{array}{l}\text { Bosner et al. } \\
{[45]}\end{array}$ & Known IHD & Interdisciplinary consensus & 56 & 122 & 509 & 525 & 0.10 & 0.81 & 0.32 & 0.51 & 0.52 & 1.11 & 47 & 32 & 50 \\
\hline $\begin{array}{l}\text { Bosner et al. } \\
{[45]}\end{array}$ & Pain worse with breathing & Interdisciplinary consensus & 138 & 123 & 427 & 524 & 0.24 & 0.81 & 0.53 & 0.55 & 1.28 & 0.93 & 47 & 53 & 45 \\
\hline $\begin{array}{l}\text { Manchikanti et } \\
\text { al. [46] }\end{array}$ & $\begin{array}{l}\text { Chronic thoracic pain: lidocaine } \\
\text { injection }\end{array}$ & Bupivacaine injection & 22 & 14 & - & - & & & 0.61 & - & & & & & \\
\hline \multicolumn{16}{|l|}{ Psychiatric } \\
\hline $\begin{array}{l}\text { Kuijpers et al. } \\
{[47]}\end{array}$ & $\begin{array}{l}\text { Anxiety subscale of the Hospital } \\
\text { Anxiety and Depression Scale } \\
\text { (HADS-A score, cut-off } \geq 8 \text { ) }\end{array}$ & $\begin{array}{l}\text { Diagnosis Anxiety disorders } \\
\text { (Mini International } \\
\text { Neuropsychiatric Interview } \\
\text { (gold standard)) }\end{array}$ & 195 & 71 & 3 & 75 & 0.98 & 0.51 & 0.73 & 0.96 & 2.03 & 0.03 & 58 & 73 & 4 \\
\hline $\begin{array}{l}\text { Demiryoguran } \\
\text { et al. [48] }\end{array}$ & Palpitation & $\begin{array}{l}\text { Anxiety disorder: HADS-A } \\
\text { score (cut-off } \geq 10 \text { ) }\end{array}$ & 18 & 25 & 31 & 80 & 0.37 & 0.76 & 0.42 & 0.72 & 1.54 & 0.83 & 31 & 41 & 27 \\
\hline $\begin{array}{l}\text { Demiryoguran } \\
\text { et al. [48] }\end{array}$ & Fear of dying & $\begin{array}{l}\text { Anxiety disorder: HADS-A } \\
\text { score (cut-off } \geq 10 \text { ) }\end{array}$ & 11 & 6 & 38 & 102 & 0.22 & 0.94 & 0.65 & 0.73 & 4.04 & 0.82 & 31 & 65 & 27 \\
\hline $\begin{array}{l}\text { Demiryoguran } \\
\text { et al. [48] }\end{array}$ & $\begin{array}{l}\text { Light-headedness, dizziness, } \\
\text { faintness }\end{array}$ & $\begin{array}{l}\text { Anxiety disorder: HADS-A } \\
\text { score (cut-off } \geq 10 \text { ) }\end{array}$ & 11 & 8 & 38 & 100 & 0.22 & 0.93 & 0.58 & 0.73 & 3.03 & 0.84 & 31 & 58 & 28 \\
\hline $\begin{array}{l}\text { Demiryoguran } \\
\text { et al. [48] }\end{array}$ & Chills or hot flushes & $\begin{array}{l}\text { Anxiety disorder: HADS-A } \\
\text { score (cut-off } \geq 10 \text { ) }\end{array}$ & 11 & 5 & 38 & 103 & 0.22 & 0.95 & 0.69 & 0.73 & 4.85 & 0.81 & 31 & 69 & 27 \\
\hline $\begin{array}{l}\text { Demiryoguran } \\
\text { et al. [48] }\end{array}$ & Shortness of breath & $\begin{array}{l}\text { Anxiety disorder: HADS-A } \\
\text { score (cut-off } \geq 10 \text { ) }\end{array}$ & 13 & 22 & 36 & 86 & 0.27 & 0.80 & 0.37 & 0.71 & 1.30 & 0.92 & 31 & 37 & 29 \\
\hline $\begin{array}{l}\text { Demiryoguran } \\
\text { et al. [48] }\end{array}$ & Nausea or gastric discomfort & $\begin{array}{l}\text { Anxiety disorder: HADS-A } \\
\text { score (cut-off } \geq 10 \text { ) }\end{array}$ & 9 & 10 & 40 & 98 & 0.18 & 0.91 & 0.47 & 0.71 & 1.98 & 0.90 & 31 & 47 & 29 \\
\hline $\begin{array}{l}\text { Demiryoguran } \\
\text { et al. [48] }\end{array}$ & Diaphoresis & $\begin{array}{l}\text { Anxiety disorder: HADS-A } \\
\text { score (cut-off } \geq 10 \text { ) }\end{array}$ & 19 & 12 & 30 & 96 & 0.39 & 0.89 & 0.61 & 0.76 & 3.49 & 0.69 & 31 & 61 & 24 \\
\hline $\begin{array}{l}\text { Foldes-Busque } \\
\text { et al. [49] }\end{array}$ & $\begin{array}{l}\text { The Panic Screening Score } \\
\text { (derivation population) }\end{array}$ & $\begin{array}{l}\text { Panic disorder diagnosis } \\
\text { (structured Anxiety Disorders } \\
\text { Interview Schedule for } \\
\text { Diagnostic and Statistical } \\
\text { Manual of Mental Disorders, } \\
\text { fourth edition DSM-IV (ADIS- } \\
\text { IV)) }\end{array}$ & 53 & 19 & 31 & 98 & 0.63 & 0.84 & 0.74 & 0.76 & 3.89 & 0.44 & 42 & 74 & 24 \\
\hline
\end{tabular}


Table 7 Summary of all tests evaluated (Continued)

\begin{tabular}{|c|c|c|c|c|c|c|c|c|c|c|c|c|c|c|c|}
\hline $\begin{array}{l}\text { Foldes-Busque } \\
\text { et al. [49] }\end{array}$ & $\begin{array}{l}\text { The Panic Screening Score } \\
\text { (validation population) }\end{array}$ & $\begin{array}{l}\text { Panic disorder diagnosis } \\
\text { (structured ADIS-IV) }\end{array}$ & 69 & 27 & 61 & 148 & 0.53 & 0.85 & 0.72 & 0.71 & 3.44 & 0.55 & 43 & 72 & 29 \\
\hline $\begin{array}{l}\text { Katerndahl et } \\
\text { al. [51] }\end{array}$ & GP diagnosis of panic disorder & $\begin{array}{l}\text { Panic disorder (structured } \\
\text { clinical Interview of Diagnostic } \\
\text { and Statistical Manual of } \\
\text { Mental Disorders, based on } \\
\text { DSM-III-R) }\end{array}$ & 2 & 2 & 26 & 21 & 0.07 & 0.91 & 0.50 & 0.45 & 0.82 & 1.02 & 55 & 50 & 55 \\
\hline Fleet et al. [50] & $\begin{array}{l}\text { Panic disorder diagnosis: formula } \\
\text { including Agoraphobia Cognitions } \\
\text { QA, Mobility Inventory for } \\
\text { Agoraphobia, Zone } 12 \text { Dermatome } \\
\text { Pain Map, Sensory McGill Pain QA, } \\
\text { Gender, Zone } 25 \text { (Validation } \\
\text { population) }\end{array}$ & $\begin{array}{l}\text { Panic Disorder (ADIS-R } \\
\text { structured interview by } \\
\text { psychologist) }\end{array}$ & 32 & 41 & 17 & 122 & 0.65 & 0.75 & 0.44 & 0.88 & 2.60 & 0.46 & 23 & 44 & 12 \\
\hline
\end{tabular}


joint and muscle dysfunction related to $\mathrm{C} 4$ to $\mathrm{T} 8$ somatic structures of the spine and chest wall established by means of joint-play and/or end-play palpation.

24-h pH-metry: 24-h pH monitoring measures with a single sensor located above the lower esophageal sphincter (LES) a reflux event and the association of the reflux event with symptoms can also be ascertained from the tracing; manometry: esophageal manometry measures mean pressure of the lower esophageal sphincter and any degree of hypomotility and dysmotility in the esophagus.

LR+, positive likelihood ratio calculated sensitivity/1 specificity; LR-, negative likelihood ratio calculated 1 sensitivity/specificity; diagnostic test accuracy. Very good: $\mathrm{LR}+>10$, LR- <0.1; good: $\mathrm{LR}+5$ to 10 , $\mathrm{LR}-0.1$ to 0.2 ; fair: $L R+2$ to 5 , LR- 0.2 to 0.5 ; poor: $L R+1$ to 2 , LR- 0.5 to 1 .

Reference tests are as follows. Endoscopic classification: LA classification: grade $\mathrm{A}, \geq 1$ mucosal break $\leq 5 \mathrm{~mm}$, that does not extend between the tops of two mucosal folds; grade $\mathrm{B}, \geq 1$ mucosal break $>5 \mathrm{~mm}$ long that does not extend between the tops of two mucosal folds; grade $\mathrm{C}, \geq 1$ mucosal break that is continuous between the tops of two or more mucosal folds but which involves $<75 \%$ of the circumference; grade $\mathrm{D}, \geq 1$ mucosal break which involves at least $75 \%$ of the esophageal circumference [52]. Savary-Miller System: grade I, single or isolated erosive lesion(s) affecting only one longitudinal fold; grade II, multiple erosive lesions, noncircumferential, affecting more than one longitudinal fold, with or without confluence; grade III, circumferential erosive lesions; grade IV, chronic lesions: ulcer(s), stricture(s) and/or short esophagus. Alone or associated with lesions of grades 1 to 3 ; grade $\mathrm{V}$, columnar epithelium in continuity with the $\mathrm{Z}$ line, non-circular, starshaped, or circumferential. Alone or associated with lesions of grades 1 to 4 [53]. Hentzel-Dent grades: grade 0 , no mucosal abnormalities; grade 1 , no macroscopic lesions but erythema, hyperemia, or mucosal friability; grade 2, superficial erosions involving $<10 \%$ of mucosal surface of the last $5 \mathrm{~cm}$ of esophageal squamous mucosa; grade 3, superficial erosions or ulceration involving $10 \%$ to $50 \%$ of the mucosal surface of the last $5 \mathrm{~cm}$ of esophageal squamous mucosa; grade 4, deep peptide ulceration anywhere in the esophagus or confluent erosion of $>50 \%$ of the mucosal surface of the last $5 \mathrm{~cm}$ of esophageal squamous mucosa [54]. pH-metry: De Meester criteria: (1) total number of reflux episodes; (2) number of reflux episodes with $\mathrm{pH}<4$ for more than 5 minutes; (3) duration of the longest episode; (4) percentage total time $\mathrm{pH}<4$; (5) percentage upright time $\mathrm{pH}<4$; and 6) percentage recumbent time $\mathrm{pH}<4$. [55]. Manometry: Spechler criteria: diagnosis of ineffective esophageal motility, nutcracker esophagus, spasm, achalasia based on: basal lower esophageal sphincter pressure, relaxation, wave progression, distal wave amplitude [56].

$A C Q$ Agoraphobia Cognitions Questionnaire, ADIS-R structured interview by psychologist, recommended interview protocol for panic research, $C V D$ cardiovascular disease, DSM-IV (ADIS-IV) Anxiety Disorders Interview Schedule, GERD gastroesophageal reflux disease, GP general practitioner, GPE Ghillibert probability estimate (sum of partial probabilities for exact numbers of reflux associated symptoms within the context of the total number of symptoms), HDR high-degree response, EoE eosinophilic esophagitis (typical abnormal EoE endoscopic findings (rings or furrows)), $I H D$ ischemic heart disease, McGill sensory McGill Pain Questionnaire sensory, MIA Mobility Inventory for Agoraphobia, MINI Mini International Neuropsychiatric Interview (gold standard for anxiety disorders), NPV negative predictive value, $P P V$ positive predictive value, $S I$ symptom index (calculated as the proportion of chest pain symptoms $(\mathrm{pH}<4)$ divided by the number of chest pain episodes recorded, expressed as a percentage), SIS symptom index score (calculated by adding the reported daily severity $($ mild $=1 ;$ moderate $=2$; severe $=3 ;$ and disabling $=4)$ multiplied by the reported daily frequency values during each week).

\section{Competing interests}

The authors declare that they have no competing interests. This study was not funded.

\section{Authors' contributions}

MW and KR carried out data extraction, participated in the analysis and drafted the manuscript. UH participated in the design of the study and performed the statistical analysis. JS conceived the study, and participated in its design and coordination and helped to draft the manuscript. All authors read and approved the final manuscript.

\section{Acknowledgements}

We thank Dr Martina Gosteli, University of Zurich, for conducting the literature search.

Received: 18 June 2013 Accepted: 15 October 2013

Published: 8 November 2013

\section{References}

1. Eslick GD, Coulshed DS, Talley NJ: Review article: the burden of illness of non-cardiac chest pain. Aliment Pharmacol Ther 2002, 16:1217-1223.

2. Kahn SE: The challenge of evaluating the patient with chest pain. Arch Pathol Lab Med 2000, 124:1418-1419.

3. Cayley WE Jr: Diagnosing the cause of chest pain. Am Fam Physician 2005, 72:2012-2021

4. Blatchford O, Capewell S, Murray S, Blatchford M: Emergency medical admissions in Glasgow: general practices vary despite adjustment for age, sex, and deprivation. Brit J Gen Pract 1999, 49:551-554.

5. Pope JH, Aufderheide TP, Ruthazer R, Woolard RH, Feldman JA, Beshansky $J R$, Griffith $\lrcorner$, Selker HP: Missed diagnoses of acute cardiac ischemia in the emergency department. N Engl J Med 2000, 342:1163-1170.

6. Buntinx F, Knockaert D, Bruyninckx R, De Blaey N, Aerts M, Knottnerus JA, Delooz $\mathrm{H}$ : Chest pain in general practice or in the hospital emergency department: is it the same? Fam Pract 2001, 18:586-589.

7. Ruddox V, Mathisen M, Otterstad JE: Prevalence and prognosis of non-specific chest pain among patients hospitalized for suspected 
acute coronary syndrome - a systematic literature search. BMC Med 2012, 10:58.

8. Nilsson S, Scheike M, Engblom D, Karlsson LG, Molstad S, Akerlind I, Ortoft K, Nylander E: Chest pain and ischaemic heart disease in primary care. Brit J Gen Pract 2003, 53:378-382.

9. Verdon F, Burnand B, Herzig L, Junod M, Pecoud A, Favrat B: Chest wall syndrome among primary care patients: a cohort study. BMC Fam Pract 2007, 8:51.

10. Svavarsdottir AE, Jonasson MR, Gudmundsson GH, Fjeldsted K: Chest pain in family practice. Diagnosis and long-term outcome in a community setting. Can Fam Physician 1996, 42:1122-1128.

11. Eslick GD, Talley NJ: Natural history and predictors of outcome for noncardiac chest pain: a prospective 4-year cohort study. Neurogastroenterol Motil 2008, 20:989-997.

12. Eslick GD, Talley NJ: Non-cardiac chest pain: predictors of health care seeking, the types of health care professional consulted, work absenteeism and interruption of daily activities. Aliment Pharmacol Ther 2004, 20:909-915.

13. Stochkendahl MJ, Christensen HW: Chest pain in focal musculoskeletal disorders. Med Clin North Am 2010, 94:259-273.

14. Katz PO: Approach to the patient with unexplained chest pain. Semin Gastrointest Dis 2001, 12:38-45.

15. Whiting P, Rutjes AW, Dinnes J, Reitsma J, Bossuyt PM, Kleijnen J: Development and validation of methods for assessing the quality of diagnostic accuracy studies. Health Technol Assess 2004, 8:iii. 1-234.

16. Maev IV, lurenev GL, Burkov SG, V'luchnova ES: Rabeprazole test and comparison of the effectiveness of course treatment with rabeprazole in patients with gastroesophageal reflux disease and non-coronary chest pain. Klin Med 2007, 85:45-51.

17. Bachmann LM, Puhan MA, Riet G, Bossuyt PM: Sample sizes of studies on diagnostic accuracy: literature survey. BMJ Clin Res Ed 2006, 332:1127-1129.

18. Carley S, Dosman S, Jones SR, Harrison M: Simple nomograms to calculate sample size in diagnostic studies. Emerg Med J 2005, 22:180-181.

19. Scottish Intercollegiate Guidelines Network: Methodology checklist 5: diagnostic studies. http://www.sign.ac.uk/methodology/checklists.html.

20. Jaeschke R: Users' guides to the medical literature. III. How to use an article about a diagnostic test. B. What are the results and will they help me in caring for my patients? The Evidence-Based Medicine Working Group. JAMA 1994, 271:703-707.

21. Rutter CM, Gatsonis CA: A hierarchical regression approach to metaanalysis of diagnostic test accuracy evaluations. Stat Med 2001, 20:2865-2884.

22. R Project: R: A language and environment for statistical computing http://www.r-project.org/.

23. Schiller I, Dendukuri N: HSROC: Joint meta-analysis of diagnostic test sensitivity and specificity with or without a gold standard reference test. In $R$ package version 2.1.6. 2013.

24. Kim JH, Rhee PL, Park EH, Son HJ, Kim JJ, Rhee JC: Clinical usefulness of subgrouping of patients with non-cardiac chest pain according to characteristic symptoms in Korea. J Gastroenterol Hepatol 2007, 22:320-325.

25. Hong SN, Rhee PL, Kim JH, Lee JH, Kim YH, Kim JJ, Rhee JC: Does this patient have oesophageal motility abnormality or pathological acid reflux? Dig Liver Dis 2005, 37:475-484.

26. Netzer $P$, Gut A, Heer R, Gries N, Pfister M, Halter F, Inauen W: Five-year audit of ambulatory 24-hour esophageal pH-manometry in clinical practice. Scand J Gastroenterol 1999, 34:676-682

27. Mousavi S, Tosi J, Eskandarian R, Zahmatkesh M: Role of clinical presentation in diagnosing reflux-related non-cardiac chest pain. J Gastroenterol Hepatol 2007, 22:218-221.

28. Singh S, Richter JE, Bradley LA, Haile JM: The symptom index. Differential usefulness in suspected acid-related complaints of heartburn and chest pain. Dig Dis Sci 1993, 38:1402-1408.

29. Ho K: Gastroesophageal reflux disease is a common cause of non-cardiac chest pain in a country with a low prevalence ofreflux esophagitis. Dig Dis Sci 1998, 43:1991-1997.

30. Lam HGT: Acute non-cardiac chest pain in a coronary care unit: evaluation by 24-hour pressure and $\mathrm{pH}$ recording of the esophagus. Gastroenterology 1992, 102:453-460

31. Dickman R, Emmons S, Cui H, Sewell J, Hernandez D, Esquivel RF, Fass R: The effect of a therapeutic trial of high-dose rabeprazole on symptom response of patients with non-cardiac chest pain: a randomized, doubleblind, placebo-controlled, crossover trial. Aliment Pharmacol Ther 2005, 22:547-555.

32. Bautista J, Fullerton $H$, Briseno $M$, Cui $H$, Fass $R$ : The effect of an empirical trial of high-dose lansoprazole on symptom response of patients with non-cardiac chest pain - a randomized, doubleblind, placebo-controlled, crossover trial. Aliment Pharmacol Ther 2004, 19:1123-1130.

33. Fass R, Fennerty MB, Ofman JJ, Gralnek IM, Johnson C, Camargo E, Sampliner RE: The clinical and economic value of a short course of omeprazole in patients with noncardiac chest pain. Gastroenterology 1998, 115:42-49.

34. Pandak WM, Arezo S, Everett S, Jesse R, DeCosta G, Crofts T, Gennings C, Siuta M, Zfass A: Short course of omeprazole - A better first diagnostic approach to noncardiac chest pain than endoscopy, manometry, or 24-hour esophageal pH monitoring. J Clin Gastroenterol 2002, 35:307-314

35. Kim JH, Sinn DH, Son HJ, Kim JJ, Rhee JC, Rhee PL: Comparison of oneweek and two-week empirical trial with a high-dose rabeprazole in noncardiac chest pain patients. J Gastroenterol Hepatol 2009, 24:1504-1509.

36. Xia HH, Lai KC, Lam SK, Hu WH, Wong NY, Hui WM, Lau CP, Chen WH, Chan CK, Wong WM, Wong BC: Symptomatic response to lansoprazole predicts abnormal acid reflux in endoscopy-negative patients with non-cardiac chest pain. Aliment Pharmacol Ther 2003, 17:369-377.

37. Kushnir VM, Sayuk GS, Gyawali CP: Abnormal GERD parameters on ambulatory $\mathrm{pH}$ monitoring predict therapeutic success in noncardiac chest pain. Am J Gastroenterol 2010, 105:1032-1038.

38. Lacima G, Grande L, Pera M, Francino A, Ros E: Utility of ambulatory 24hour esophageal $\mathrm{pH}$ and motility monitoring in noncardiac chest pain: report of 90 patients and review of the literature. Dig Dis Sci 2003, 48:952-961.

39. Cooke RA, Anggiansah A, Smeeton NC, Owen WJ, Chambers JB: Gastroesophageal reflux in patients with angiographically normal coronary-arteries - an uncommon cause of exertional chest pain. Br Heart J 1994, 72:231-236.

40. Bovero E, Torre F, Poletti M, Faveto M, De laco F: Exertional gastroesophageal $\mathrm{pH}$-metry: a new provocative physiological test in the diagnosis of chest pain. Gastroenterol Clin Biol 1993, 17:4-8.

41. Romand F, Vincent E, Potier V, Claudel N, Galoo E, Desbaumes J: Anginalike chest pain and exertional esophageal $\mathrm{pH}$ monitoring. Gastroenterol Clin Biol 1999, 23:313-318.

42. Abrahao $L J \mathrm{Jr}$, Lemme EMO: Role of esophageal provocative tests in the investigation of patients with chest pain of undetermined origin [in Portugese]. Arq Gastroenterol 2005, 42:139-145.

43. Achem SR, Almansa C, Krishna M, Heckman MG, Wolfsen HC, Talley NJ DeVault KR: Oesophageal eosinophilic infiltration in patients with noncardiac chest pain. Aliment Pharmacol Ther 2011, 33:1194-1201

44. Stochkendahl MJ, Vach W, Hartvigsen J, Hoilund-Carlsen PF, Haghfelt $T$, Christensen HW: Reconstruction of the decision-making process in assessing musculoskeletal chest pain: an exploratory study using recursive partitioning. J Manipulative Physiol Ther 2012, 35:184-195.

45. Bosner S, Becker A, Hani MA, Keller H, Sonnichsen AC, Karatolios K, Schaefer $J R$, Haasenritter J, Baum E, Donner-Banzhoff N: Chest wall syndrome in primary care patients with chest pain: presentation, associated features and diagnosis. Fam Pract 2010, 27:363-369.

46. Manchikanti L, Singh V, Pampati V, Beyer CD, Damron KS: Evaluation of the prevalence of facet joint pain in chronic thoracic pain. Pain Physician 2002, 5:354-359.

47. Kuijpers PM, Denollet J, Lousberg R, Wellens HJ, Crijns H, Honig A: Validity of the hospital anxiety and depression scale for use with patients with noncardiac chest pain. Psychosomatics 2003, 44:329-335.

48. Demiryoguran NS, Karcioglu O, Topacoglu H, Kiyan S, Ozbay D, Onur E, Korkmaz T, Demir OF: Anxiety disorder in patients with non-specific chest pain in the emergency setting. Emerg Med J 2006, 23:99-102.

49. Foldes-Busque G, Fleet R, Poitras J, Chauny JM, Belleville G, Denis I, Diodati JG, Pelland ME, Lessard MJ, Marchand A: Preliminary investigation of the Panic Screening Score for emergency department patients with unexplained chest pain. Acad Emerg Med 2011, 18:322-325. 
50. Fleet RP, Dupuis G, Marchand A, Burelle D, Beitman BD: Detecting panic disorder in emergency department chest pain patients: a validated model to improve recognition. Ann Behav Med 1997, 19:124-131.

51. Katerndahl DA, Trammell C: Prevalence and recognition of panic states in STARNET patients presenting with chest pain. J Fam Pract 1997, 45:54-63.

52. Lundell LR, Dent J, Bennett JR, Blum AL, Armstrong D, Galmiche JP, Johnson F, Hongo M, Richter JE, Spechler SJ, Tytgat GN, Wallin L: Endoscopic assessment of oesophagitis: clinical and functional correlates and further validation of the Los Angeles classification. Gut 1999, 45:172-180.

53. Genta RM, Spechler SJ, Kielhorn AF: The Los Angeles and Savary-Miller sys tems for grading esophagitis: utilization and correlation with histology. Dis Esophagus 2011, 24:10-17.

54. Pandolfino JE, Vakil NB, Kahrilas PJ: Comparison of inter- and intraobserver consistency for grading of esophagitis by expert and trainee endoscopists. Gastrointest Endosc 2002, 56:639-643.

55. De Meester TR, Wang Cl, Wernly JA, Pellegrini CA, Little AG, Klementschitsch $P$, Bermudez G, Johnson LF, Skinner DB: Technique, indications, and clinical use of 24 hour esophageal pH monitoring. J Thorac Cardiovasc Surg 1980, 79:656-670.

56. Spechler SJ, Castell DO: Classification of oesophageal motility abnormalities. Gut 2001, 49:145-151.

57. Katz P, Gerson L, Vela M: Guidelines for the diagnosis and management of gastroesophageal reflux disease. Am J Gastroenterol 2012, 108:308-328.

58. Eslick GD, Fass R: Noncardiac chest pain: evaluation and treatment. Gastroenterol Clin North Am 2003, 32:531.

59. Achem SR, DeVault KR: Recent developments in chest pain of undetermined origin. Curr Gastroenterol Rep 2000, 2:201-209.

60. Chambers J, Bass C: Atypical chest pain: looking beyond the heart. QJM 1998, 91:239-244.

61. Yelland M, Cayley WE Jr, Vach W: An algorithm for the diagnosis and management of chest pain in primary care. Med Clin North Am 2010 94:349-374.

62. Cremonini F, Wise J, Moayyedi P, Talley NJ: Diagnostic and therapeutic use of proton pump inhibitors in non-cardiac chest pain: a metaanalysis. Am J Gastroenterol 2005, 100:1226-1232.

63. Kahrilas PJ, Hughes N, Howden CW: Response of unexplained chest pain to proton pump inhibitor treatment in patients with and without objective evidence of gastro-oesophageal reflux disease. Gut 2011, 60:1473-1478.

64. Chambers J, Cooke R, Anggiansah A, Owen W: Effect of omeprazole in patients with chest pain and normal coronary anatomy: initial experience. Int J Cardiol 1998, 65:51-55.

65. Dekel R, Martinez-Hawthorne SD, Guillen RJ, Fass R: Evaluation of symptom index in identifying gastroesophageal reflux disease-related noncardiac chest pain. J Clin Gastroentero 2004, 38:24-29.

66. Adamek RJ, Wegener M, Wienbeck M, Pulte T: Esophageal motility disorders and their coexistence with pathological acid reflux in patients with noncardiac chest pain. Scand J Gastroenterol 1995, 30:833-838.

67. Achem SR, Kolts BE, MacMath T, Richter J, Mohr D, Burton L, Castell DO: Effects of omeprazole versus placebo in treatment of noncardiac chest pain and gastroesophageal reflux. Dig Dis Sci 1997, 42:2138-2145.

68. Harbord RM, Deeks JJ, Egger M, Whiting P, Sterne JA: A unification of models for meta-analysis of diagnostic accuracy studies. Biostatistics 2007, 8:239-251.

69. Dendukuri N, Schiller I, Joseph L, Pai M: Bayesian meta-analysis of the accuracy of a test for tuberculous pleuritis in the absence of a gold standard reference. Biometrics 2012, 68:1285-1293.

70. Leeflang MMG, Rutjes AWS, Reitsma JB, Hooft L, Bossuyt PMM: Variation of a test's sensitivity and specificity with disease prevalence. Can Med Assoc J 2013, 185:E537-E544.

doi:10.1186/1741-7015-11-239

Cite this article as: Wertli et al:: Diagnostic indicators of non-

cardiovascular chest pain: a systematic review and meta-analysis. BMC

Medicine 2013 11:239.

\section{Submit your next manuscript to BioMed Central and take full advantage of:}

- Convenient online submission

- Thorough peer review

- No space constraints or color figure charges

- Immediate publication on acceptance

- Inclusion in PubMed, CAS, Scopus and Google Scholar

- Research which is freely available for redistribution 